\title{
Soybean in the European Union, Status and Perspective
}

\author{
Yves Bertheau ${ }^{1}$ and John Davison ${ }^{2}$ \\ ${ }^{1}$ Inra SPE, route de Saint Cyr, 78026 Versailles cedex, \\ 2 Inra, route de Saint Cyr, 78026 Versailles cedex(retired)
}

France

\section{Introduction}

Originating from China, soybean is currently the most important agricultural commodity traded around the world, both in terms of volumes and money. This crop also shows the most important changes over the last decades by the predominance of genetically modified (GM) crops, dominated by herbicide tolerance traits, and its worldwide cultivation. Due to its important protein content and the increasing demand for proteins in relation with the intensification of livestock production, the soybean surfaces have dramatically increased in several South American countries, such as Brazil, Argentina, Paraguay, Uruguay and Bolivia when compared to the surfaces of soybean in the USA, and at a less extent in Canada (James, 2011). China is still the main (non-GM) soybean producer but the main exporters of (GM) soybean are the USA, Brazil and Argentina. China which was, until the 1930s, the main worldwide exporter but was dethroned in the 1950s by USA exporting soybean as basis of feedstuffs and China is now the main importer with ca $60 \%$ of US soy.

The success of GM soybean can be explained by the ease of cropping due to GM trait in countries with large fields, particularly for farmers for whom weed management and soil erosion have always been an issue.

This segmentation of market between food and feed use is still prevalent into the international trade: Asia mostly cultivates and uses non-GM soybean as a food component while other regions of the world mostly use GM and non-GM soybean as feed component (Birthal et al., 2010). However, since a few years, this trend is changing with the improvement of the living standards of Asian countries such as China, which now imports huge quantities of soybean for livestock feeding due to an increased demand for meat. Currently, the soybean daily price is at its second highest peak after the 2007/2008 peak. Altogether, the soybean daily price increased of only $83 \%$ over the 3 last decades due to the current prices' peak (IndexMundi, International Monetary Fund. April 20, 20111).

Despite the fact that several other sources of protein are available for livestock, the flexibility of soybean in feedstuff preparation, particularly for pork and poultry productions, drives the international trade. Its use in bovine production, meat or milk, can be more easily replaced by alternative protein sources, or simply be replaced by pasturage.

${ }^{1} \mathrm{http}: / /$ www.indexmundi.com/commodities/?commodity=soybeans\&months=360 
Soybean has been first introduced in Europe during the XVIIth century as high-class food, however despite several scientific and popular reports during the XIXth century soybean was rarely cropped in Western Europe. The first massive importation of soybean in Europe started by the beginning of the $X X^{\text {th }}$ century for oil and meal production, declined during the 2 world wars, but with increasing imports between them. Since the 1950s, Europe dramatically increased its importations of soybean due to a new animal production scheme with highly concentrated livestock production. However, new dossiers in the pipeline of GMO approvals now consider cultivation in the EU. We thus examine in more depth this forthcoming issue in environmental surveillance.

Due to this increasing part of GM soybean in the international market and consumers' reluctance of several countries to accept these products, a new segmentation of the market appeared between GM and non-GM soybean linked to labeling of GM food, and feed in some countries, with an exemption of labeling below a threshold of fortuitous or technically unavoidable presence, ranging from $0.9 \%$ in the EU-272 and Russia to 3-5\% in Korea, Taiwan and Japan. Generally speaking, the labeling thresholds are representative of the countries' dependence on feed and food imports.

\section{GMO in the EU}

The development of green biotechnology dates back to the 1970s and led to the development of Genetically Modified Organisms (GMOs) in the 1980s. On May 21, 1994, the genetically engineered FlavrSavr ${ }^{\mathrm{TM}}$ tomato was the first crop approved by the U.S. Food and Drug Administration for commercialization. Due to the controversy over GMOs, which started with the first arrivals in Europe of soybeans cargoes in 1996, and to its poor organoleptic qualities, this tomato was withdrawn from the market in 1998 (Bruening and Lyons, 2000).

\subsection{European consumers}

Today, around 148 million hectares of GM plants are grown and traded around the world annually, among which ca. 71\% of GM soy according to the ISAAA lobbyist (James, 2011). Despite this development, the European public's perception of GM crops is still very negative as demonstrated by the recent results of the Eurobarometer surveys (Bonny, 2008; de Cheveigné, 2004; Gaskell et al., 2006; Gaskell et al., 2010; TNS Opinion \& Social, 2010). However, this consumers' reluctance seems less pronounced in the eastern part of the EU-27 (Consumerchoice Consortium, 2008).

After several scandals in the 1990s' such as BSE, dioxin contaminations, the reluctance of consumers' and citizens to embrace GMOs has been considered by the EC and European Union Member States (EU-MS) which have implemented a legal framework enabling consumers to maintain their freedom of choice through both food and feed labeling (European Commission, 1997, 2000a, b, 2001, 2002d, 2003c, d). In counterpart, the freedom of choice of producers to cultivate GM or non-GM crops is considered through a set of coexistence rules to be implemented by EU-MS, according to the European principle of subsidiarity as recommended by the EC (European Commission, 2003a, 2010a). However, despite numerous requests from NGOs and consumers associations, animals reared with GM feed do not require labeling.

\footnotetext{
${ }^{2}$ Current European Union with 27 Member States
} 


\subsection{GMO approvals in the EU}

In order to re-assure the European public on food safety and more particularly the question of GMOs, the European Community has developed a series of regulations (Table 1) to ensure GMO safety, detection, traceability and labeling.

Food safety assessment is the responsibility of the European Food Safety Authority (EFSA) which cooperates with EU-MS national advisory committees and covers food additives, animal welfare, plant health, allergies, mycotoxins, biological hazards, chemical and biological contaminants. It also assesses the safety of GMOs (seed, food, feed, and derivatives). EFSA is an independent scientific body providing advice on all aspects of food safety, and a positive EFSA assessment is necessary for authorization to place food on the European market. GMO dossiers can be notified to the European Commission either under the 2001/18 directive or the (EC) regulation 1829/2003. Although not implied in its name, EFSA also provides advice on GMO environmental issues.

Once a positive EFSA assessment has been obtained, and once validated GMO detection methods and control sample and reference materials are available (all being provided by the applicant company), the application is then sent to the EC. On the basis of the opinion of EFSA, in some instances amended on the basis of national advisory agencies and committees, the EC drafts a proposal for granting or refusing the authorization, which it submits to the Section on GM Food and Feed of the Standing Committee on the Food Chain and Animal Health. If this Standing Committee accepts the proposal, it is finally adopted by the EC. Otherwise, it is passed on to the Council of Ministers which has a time limit of 3 months to reach a qualified majority for, or against, the proposal. In the absence of such a decision (which is frequently the case), the EC adopts the proposal. Over the last years, all GMO approvals in the EU were accepted on that scheme basis with approvals for a renewable 10 years period.

In contrast to several claims against the "lengthy and costly" approval European procedure, it should be noted that the notifiers often use dossiers of previous approvals in third countries, such as USA, with thus very few changes and thus very low costs of compliance with the EU approval procedure. Secondly, the European theoretical approval duration is per se not very long; however dossiers are in numerous instances incomplete. In this case the clock of approval is stopped each time details are requested from the notifiers. Due to these several stop-and-go steps in such an approval, the effective duration of European approval may be rather long. The European procedure of safety assessment of GMOs is currently under review, for instance on the statistics to be used in comparing animal cohorts, the guidelines about environmental impact assessment, or the more important use of the "substantial equivalence" concept in the comparisons between GM and conventional plants. Despite the relatively rather strict European approval procedure, several EU-MS introduced national bans on GMO, be these for import and transformation such as Austria, for baby food in Italy or for cultivation as in France, Austria or Bulgaria.

However, there are currently ca. 50 GMOs in the pipeline of approval or approved for import and transformation, including several stacked GMOs and a few modified flowers. For soybean, 11 transformation events or stacked genes are in the European approval process with 2 GM soybean as fully approved and the first approved one (MON GTS 40-3-2) in the renewal process.

Due to the rather long European approval process, several reports outlined the possible shortage of soybean for the feed industry due to these "asynchronous approvals" (DG AGRI European Commission, 2007; Stein and Rodriguez-Cerezo, 2009, 2010a). The EC recently 
issued a proposal of modification of 2001/18 directive to allow Low Level Presence of EU unapproved GMOs, as also discussed in the Codex Alimentarius instance, for GMO already approved in a third country and whose dossiers are already under EFSA discussion for at least 3 months.

- Directive 1990/219/EEC covered the contained use of genetically modified organisms. Directive 1990/220/EEC was modified by Directive 98/81/EEC.

- Directive 1990/220/EEC covered the notification for a deliberate release and of the placing on the market of GMOs. Directive 1990/220/EEC was repealed by Directive 2001/18/EEC.

- Regulation (EC) 258/1997 concerning novel foods and novel food ingredients, not heavily used in the EU before 1997 and establishing a compulsory labeling for these novel foods and ingredients, such as GMO, irradiated food, etc. Part of the current revision of food and feed legislation.

- Regulation (EC) 1139/1998 laid down the compulsory indication on the labeling of foods and food ingredients produced from genetically modified soya (Glycine max L.) covered by Commission Decision 1996/281/EC and genetically modified maize (Zea mays L.) covered by Commission Decision 1997/98/EC, of particulars other than those provided for in Directive 1979/112/EEC.

- Regulation (EC) 49/2000 amended the 1139/1998 EC regulation and established a 1\% labeling threshold which was further decreased to $0.9 \%$ by regulation $1829 / 2003$.

- Regulation (EC) 50/2000 establishing a mandatory labeling of additives and flavorings that have been genetically modified or have been produced from genetically modified organisms.

- Directive 2001/18/EEC covers the deliberate release of GMOs in the environment (field trials and cultivation), in the absence of specific containment measures. It also regulates commercialization (importation, processing and transformation) of GMOs into industrial products. Finally, the Directive requests post-commercialization, case specific and general, surveillance plans on unforeseen effects of GMO on both health and environment.

- Regulation (EC) 178/2002 resulted in the creation of EFSA and in a general obligation for traceability of at least one step forwards and one step backwards in the food chain.

- Regulation (EC) 1946/2003 is concerned with the trans-boundary movement, and accompanying documentation, for LMOs (living modified organisms) destined for deliberate release, or for food and feed or for immediate processing, under the terms of the Cartagena Protocol on Biosafety.

- Regulation (EC) 1829/2003 covers mainly the commercialization of food and feed. It facilitates GMO detection by obliging the providers of GMO plants to disclose methods for their detection (Regulation (EC) 1981/2006 provides for a fee to be paid by the applicant to the CRL for this service). These methods are then verified and validated by the EURL-GMFF, hosted by the DG JRC laboratory of Ispra (Italy) with the support of the ENGL, before being made public. This regulation imposes labeling for authorized GMOs above a threshold of $0.9 \%$. Labeling is not required for conventional or organic food and feed containing the adventitious, or technically unavoidable, presence of authorized GMOs at levels less than $0.9 \%$. Unauthorized GMO are not permitted entry in the EU, even at levels less that $0.9 \%$ (the so-called "zero tolerance"). 
- Regulation (EC) 1830/2003 concerns the traceability and labeling of genetically modified organisms and the traceability of food and feed products produced from genetically modified organisms and amending Directive 2001/18/EC. It imposes a specific traceability requirement on GMOs, over and above that of the general traceability regulation 178/2002. Traceability archives must be kept for five years.

- Regulation (EC) 65/2004 establishes a system for the development and assignment of unique identifiers for genetically modified organisms.

- Regulation (EC) 882/2004 on official controls performed to ensure the verification of compliance with feed and food law, animal health and animal welfare rules.

- Regulation (EC) 1981/2006 establishing a financial contribution on a flat-rate basis in order to contribute to supporting the costs incurred by the EURL-GMFF in the methods' validations.

Table 1. summarized overview of the European legislative frame on GMO.

After the commercial withdrawal of Event 176 maize, only 2 GM plants are currently approved for cultivation in the EU, namely the MON 810 maize and the Amflora ${ }^{\circledR}$ potato. However several other GMOs are in the pipeline for cultivation approvals, such as Bt11 maize or GTS 40-3-2 soybean. In this later case, Romania, which was cultivating GTS 40-3-2 soybean before its entrance in 2007 in the EU, is pushing hard for this approval.

In December 2008, the European council of ministries in charge of Environment asked for a reform of the EFSA approval process and for integrating socio-economic factors into the approval considerations. So far, only the French High Council of Biotechnologies integrates such considerations into its advice system through its Economic, Ethical and Social Committee $^{3}$ due to a recent law (République Française, 2008).

\subsection{Labeling and traceability}

According to (EC) 178/2002 regulation, traceability is mandatory in the EU for all food items, one step forward - one step backward, with additional specific requirements for GM products such as keeping traceability document for at least 5 years as described below and in Table 1.

The operation of GMO food control systems (e.g. detection, labeling and traceability methods) are not within EFSA's remit, and remain the responsibility of the EC, through the European Reference Laboratory for Genetically Modified Food and Feed (EURL-GMFF), and the Competent Authorities (CA) of individual EU-MS. It should be noted, since it is a source of frequent miscomprehension, that EC traceability and labeling regulations are not concerned with GMO safety, risk evaluation or risk management, since food that does not have a positive EFSA assessment does not reach the market. Traceability data on food and feed, including GMOs, may serve, however, to enable the re-call of products from the supermarkets in the case of unforeseen mishaps, such as the accidental or deliberate contamination of food chains. Traceability is a non-discriminatory and inexpensive requirement since most of the companies already have quality assurance protocols in place and since numerous analyses are routinely carried-out for multiple purposes, including vitamin or toxins contents. Quality assurance procedures offer several advantages to the companies such as specific market niches, efficient low-cost withdrawal of products and easier implementation of control procedures for future mandatory requirements (e.g.

\footnotetext{
${ }^{3}$ Comité économique, éthique et social (CEES)
} 
traceability and labeling of allergens in food and feed). Fees incurred by the EURL-GMFF, for validating the detection methods by inter-laboratory trials, are on a flat-rate covered by a financial contribution of the notifying companies while a new network of National Reference Laboratories has been established beside the European Network of GMOs Laboratories (ENGL) (European Commission, 2004d, 2006a). The EC released several reports on traceability experience in the EU-MS (European Commission, 2006d, 2008b).

So far there is no European obligation of labeling animals, or their derived products, reared on GM feed despite several requests of NGOs 4 and consumers associations. However, this possibility of animal and derived products labeling has been recently introduced in Austria and Germany with a threshold of $0.9 \%$. More generally speaking, GMO-free labeling has been introduced at $0.9 \%$ in Germany and Austria, while France is currently considering a definition of GMO-free products at $0.1 \%$ according to the recommendation of the Economic, Ethical and Social Committee ${ }^{5}$ of its High Council of Biotechnology 6 (http://agriculture.gouv.fr/remise-de-l-avis-du-haut-conseil). GMO-free labeling is currently used by several German companies for e.g. milk which according to some claims increased their market shares (http://www.bund.net/bundnet/themen_und_projekte/ gentechnik/verbraucherinnenschutz/kennzeichnung/nutzende_unternehmen/).

Since the first commercialization of GMOs in third countries, the EU has been facing a great number of alerts (Davison and Bertheau, 2007, 2008). In most of the cases, these alerts resulted from a misappropriate segregation of approved GMO (Starlink ${ }^{\mathrm{TM}}$ maize), or the seeds' commercialization of unapproved GMOs (US Bt10 instead of Bt11 maize), or the release of unapproved GMOs as in the case of US LL601 rice or Chinese Bt63 and Kefeng 6 rice. While the issues of presence of unapproved GMO in domestic markets were previously considered as an issue for countries with labeling policies, the recent increase of GMOs from emerging countries led to the reaction of the US agencies (APHIS News release, 2010; GAO, 2008). In several ways, it appears that USA will move toward a more surveying attitude similar to the EU (Davison, 2010).

The issue of domestic unapproved GMO in local market is the basis of the current work of Codex Alimentarius on the Low Level Presence (Codex Alimentarius, 2003). Asynchronous approvals of GMOs has been recently taken into consideration by the EC which proposed a $0.1 \%$ presence in feedstuffs of EU unapproved GMOs after a revision of EU legislative frame (Aramyan et al., 2009a; Reuter, 2010; Stein and Rodriguez-Cerezo, 2010b).

However, the recent results of the European research project Co-Extra (www.coextra.eu) show that supply chains operators already use a contractual threshold of ca. $0.1 \%$ for the 0.9\% European labeling threshold (European Commission, 2010b). Together with the possible labeling of animals reared with GMOs, between 0.9 and $0.1 \%$, and below $0.1 \%$, such a situation will drastically impact on the availability of "GMO-free" products. The reaction of consumers toward this new European proposal remains currently unknown as ex ante studies appear very difficult for providing accurate results.

Generally speaking, the European traceability greatly improved over the last decade but with still several issues such as the sowing of EU unapproved Bt11 in France a few years ago. In these circumstances, the recent approval of a GM potato, specifically destined for

${ }^{4}$ Non Governmental Organization

${ }^{5}$ Comité économique, éthique et social

${ }^{6}$ Haut Conseil des Biotechnologies (HCB) 
industrial uses, may lead to the same issue of inappropriate segregation as the US Starlink ${ }^{\mathrm{TM}}$ maize (Miller, 2010).

\section{European GMO coexistence issues}

\subsection{General overview}

The freedom to producers to either produce GM, conventional or organic crops is the counterpart and the necessary basis of consumers' freedom to choose, or not, GMO into their food. Accordingly, the EC released in 2003 and updated in 2010 a recommendation on the coexistence of GM, conventional and organic farming (European Commission, 2003a, 2010a). Practical implementation and rules is the responsibility of the EU-MS according to the European subsidiarity principle. In parallel, several European regions declared themselves as GMO-free (http://www.gmofree-euregions.net:8080/servlet/ae5Ogm) despite the fact that some do not have the administrative legality for such a positioning. The European Commission reported on implementation of coexistence rules in EU-MS which is far from being implemented in a harmonized way in all EU-MS (European Commission, 2006b, 2009e). COEX-NET is a network established to facilitate the exchange of information on coexistence issues between EU-MS CA.

Different national (French ANR-OGM, British Farm Scale Evaluation, German BMBF project, etc.) and European (SIGMEA, Transcontainer, Co-Extra) research programs were launched the last decade to establish the scientific bases of coexistence. To aid national Competent Authorities, the EC has recently created a new 'co-existence bureau' specific for co-existence issues, at JRC-IPTS7, Seville, Spain, which recently released its first document on maize crops coexistence (Czarnak-Kłos and Rodríguez-Cerezo, 2010). If most of the current work focused on maize, currently the only plant sown, several other crops have been studied from a coexistence viewpoint, as for instance oilseed rape and sugar beet, two crops for which ferals and crossing with wild relatives are important in the EU (Colbach, 2009; Colbach et al., 2009; Darmency et al., 2009; Darmency et al., 2007; Gruber et al., 2008).

Up to now 2 trends can be distinguished in the European coexistence schemes, a flexible coexistence frame and one based on dedicated production areas, be these GMO or GMO-free.

Until now, coexistence research has mostly focused on flexible coexistence, that is to say, the individual choice of a farmer, with a minimum of ex-ante duties (such as isolation distances, buffer and/or discard zones) together with an information system, including, for instance, a public register of GM crops to provide information to non-GM growing neighbors coupled with some ex-post economic solutions such as compensation schemes for economic losses (Demont et al., 2010; Demont et al., 2009; Desquilbet and Bullock, 2010; Devos et al., 2009; Messéan et al., 2006; Messéan et al., 2009). Current EU best practice guidelines and companies' stewardships for coexistence measures in maize give effective measures for the European $0.9 \%$ threshold by requesting separation distances, buffer and discard zones, and staggered flowering times, but without taking into consideration the threshold of $0.1 \%$ used by companies due to measurements and sampling uncertainties (Bartsch et al., 2009; Bock et al., 2002; European Commission, 2010b).

Generally speaking, the proposed flexible coexistence solutions are based on the assumption that individual choices should prevail, but information systems need to be available to allow other producers to know what is being produced and where, such as those already

${ }^{7}$ European Commission's Joint Research Centre, Institute for Prospective and Technological Studies 
deployed in Portugal. However, at the same time territory / landscape multi-functionality is requested by the EU, and there is a growing call from consumers, and society as a whole, for both more sustainable production and so called quality-oriented produce as shown by the current yearly increase of ca. $20 \%$ of organic and other signs-of-quality based farming (Laisney, 2011). This leads to a conflict as GM produce is not seen as organic, even if it can be produced without, or with less pesticide, although it can definitely be more sustainable with yield increases over conventional farming (Cardwell, 2003; Grossman, 2003; Laurent et al., 2010; Marsden, 2008). Moreover, territory organization, with Natura 2000 areas (protected environmental areas, for example), is not taken into account by the flexible coexistence scheme while their domino impact is highly recognized (Demont et al., 2008). This dichotomy needs to be addressed. Finally, the landscape is highly structured by downstream supply chains (Coléno, 2008; Hannachi et al., 2009; Le Bail et al., 2010; Petit, 2009).

Due to the several requests of EU-MS to take into consideration socio-economic aspects into GMO approval, the 2010 updated EC recommendation considers more favorably the possibility of GMO-free areas. However the EC would not accept that requests by EU-MS be based on scientific or environmental grounds which are already assessed by EFSA. This last restriction is currently actively fought at the European Parliament. As a first demonstration of EU policy change, the Portuguese Madeira archipelago was established as the first GMOfree area, though cultivation of maize is relatively scarce in Madeira (Kanter, 2010).

On the opposite side, dissemination over long distance of pollen as well as the practical effect of the contractual threshold of operators militates in favor of dedicated production areas (Brunet et al., 2011; European Commission, 2010b). However, the research work on technical, economic and societal issues raised by this solution are drastically missing and the subject of strong opposition (DEFRA, 2006; Devos, 2008; Dobbs, 2011; European Economic and Social Committee, 2011; Jank et al., 2006; Sabalza et al. 2011).

As soybean is mostly an autogamous plant, numerous issues raised by pollen dissemination should not hamper the soybean cultivation in the EU. Similarly, the absence of out-crossing to wild-relatives, ferals and volunteers should facilitate the cultivation of GM soybean into a coexistence frame. However, the predominant herbicide trait would probably cause the same problems of resistant weeds as observed in the USA (Brasher, 2010; Cerdeira and Duke, 2006, 2007; Roberson, 2010). Transportation of GMO was identified as the cause of several incidental releases in the EU and third countries, including the growth of GM plants around harbors (Kawata et al., 2009; Kim et al., 2006; Lee et al., 2009).

Thus, due to its biological properties and despite the different structure of European farms and territories, the coexistence in the EU of GM and non-GM soybeans should be one of the easiest to implement; as it is in several third countries exporting non-GM soybean despite important GM soybean cropping.

\section{Surveillance plans}

Post-market release monitoring of GMOs approved both for import and cultivation (European Commission, 2001, 2003c) is one of several requests included in European GMO approval. According to the pre-market risk assessment (RA), this monitoring can be divided into case-specific monitoring (CSM), which covers any identified risk, and general surveillance (GS) for all risks that might not have been identified during the RA. EFSA published a series of documents about RA, CSM, and GS (Bartsch et al., 2006a; EFSA GMO 
Panel, 2004, 2006a, b, 2010). Several guidance documents and reports on implementation of the monitoring were then published (Bartsch et al., 2006b; Bartsch et al., 2007; EU working group, 2003; European Commission, 2002a, b, c, 2004b, 2008b, 2009a).

Monitoring of the GMOs post-market release should include both health and environmental effects, should be carried out by the GMO consent holders, i.e. the companies having received a grant for a commercial release of a GMO, and may be supported by additional independent actions of EU-MS. The CSM and GS shall cover both GMO and non-GMO cultivated areas (EFSA, 2008; EFSA GMO Panel, 2004, 2006a).

Up to now, most of the surveillance activities of GMOs approved for import and processing have been delegated by the consent holders to European professional unions of importers, transporters, and processors, namely COCERAL, UNISTOCK and FEDIOL. However, the content of agreements between consent holders and such unions remains unknown. Due to the lack of precision, in particular about the methodology used for monitoring imported GMOs, the accuracy of such monitoring plans remains undetermined for the EFSA, GMO national advisory committees, and CA in charge of GMOs (Beissner et al., 2006).

As noted above, health and environmental monitoring, which also means animal health, of predictable and unexpected effects of GMO cultivation is mandatory in the EU on both GMO and non-GMO cropped areas (European Commission, 2001, 2002a, b, 2003c).

\subsection{Specific surveillance}

In the EU, several GMO CSM protocols have been pursued by notifiers, scientists, and enforcement authorities. A decade after the first GMO cultivation in the EU, a number of guidelines, conceptual frameworks, and reports are available for GMO CSM (Bartsch et al., 2007; Bontemps et al., 2004; Bourguet, 2004; Chaufaux et al., 2002; EU working group, 2003; European Commission, 2009b; Monsanto Co., 2006, 2009a, b). The consent holders 8 published results of insect resistance monitoring, but only from GMO cropped areas despite the European rules (Monsanto Co., 2006, 2009a, b).

\subsection{General surveillance}

This part of the chapter focuses on the monitoring activities of unexpected effects of GMO cultivation, i.e. general surveillance.

GMO GS frameworks proposed by GMO consent holders in relation to EFSA guidelines include literature survey, development and / or use of existing monitoring surveillance, and specific trials as necessary (EFSA GMO panel, 2006b, 2010).

General surveillance is designed to detect unanticipated effects on general safeguarded subjects such as natural resources, which must not be adversely affected by human activities like GMO cultivation. Monitoring has to be appropriate for detecting direct and indirect effects, immediate and long-term effects, as well as unforeseen effects. In its 2006 opinion, the EFSA GMO panel outlined that: "general surveillance cannot be hypothesis driven, but should, when possible, make use of existing monitoring systems in addition to more focused monitoring systems (e.g. farm questionnaires). Data quality, management and statistical analysis are of high importance in the design of general surveillance plans and comparison should be made with baseline data" (EFSA GMO panel, 2006b). A public consultation on the 2010 version of EFSA GMO panel opinion on GS is currently ongoing.

\footnotetext{
${ }^{8}$ Notifiers having received European approval for GMO import and/or cultivation.
} 
The 2010 draft version of EFSA guidelines shows a drastic change of paradigm in the principle of environment GS and still does not establish guidelines for health effects surveillance. This draft version particularly outlines the importance of baselines, use and assessment of indicators after field trials, less oriented biodiversity studies without a priori, etc. This difference between 2006 and 2010 version may represent both the change into the EFSA GMO panel composition as well as an attempt of EU-MS, of their enforcement agencies and of the EC to master and retrieve the leadership in a scientific, but also highly political, issue.

For several years now, important scientific conceptual and practical works have indeed been developed in several EU-MS along with reports from national committees in charge of GMO approvals (ACRE, 2004; Breckling and Reuter, 2006; Garcia-Alonso et al., 2006; Graef et al., 2005; Monkemeyer et al., 2006; Wilhelm et al., 2009; Wolt et al., 2010; Zughart et al., 2008).

Most of these scientific works focused on environmental effects, while the effects on human health are roughly "delegated" by the consent holders to national health monitoring networks (Bakshi, 2003; Cellini et al., 2004; Covelli and Hohots, 2003; D'Agnolo, 2005; EFSA GMO panel, 2006b; Filip et al., 2004; Hepburn et al., 2008; Wal et al., 2003). To provide an example of EU-MS, in France, the "Sentinelles" network, ANSES9, and InVS10 might form parts of such a general surveillance plan on human health in application of the WHO and European rules, directives, and regulations. Animal health is relevant to the OIE ${ }^{11}$ and European rules, directives, and regulations. As for GMO CSM and GS, the French Ministry of Agriculture (DGAl directorate) is in charge of animal health surveillance. However, no GMO-related GS activities in human and animal health are clearly identified in the European activity reports.

Indeed, GS of human and animal health is also particularly important given that GMOs not dedicated to food and feed purposes will rapidly arrive on the market as exemplified by the recent European approval of Amflora ${ }^{\circledR}$ potato for cultivation. For this kind of split approval, we must remember the first such issue raised by the incorrect segregation between food and feed/ industry storage facilities of the USA-approved Starlink ${ }^{\mathrm{TM}}$ maize (Alderborn et al., 2010; Beckie et al., 2010; Miller, 2010). Despite the past European experience of segregating crops dedicated to industrial uses as part of a specific derogatory cultivar list, the additional recent request Modena GM potato cultivation approval in the EU can lead us expect that more and more GMO dedicated to industrial use will enter the food chain and raise new controversies about human health.

From a decade of GMO cultivation in the EU, several remarks can be made about environmental GS reported by consent holders, scientists, and enforcement authorities.

- The consent holders include a literature survey and questionnaires to GMO cropping farmers and collaboration with existing networks in their environmental GS, as was done in Germany after the German Competent Authorities (CA) approval. However, in that latter case, a great deal of imprecision remains about the content of agreements with existing networks, the network's possible training, and the surveyed locations, i.e. representativeness and accuracy of the GS, particularly in non-GMO areas. Moreover, no statistics are provided which might alert the CA to start more in depth monitoring.

\footnotetext{
${ }_{9}^{9}$ Agence Nationale de Sécurité Sanitaire

${ }^{10}$ Institut National de Veille Sanitaire

${ }^{11}$ Office International des Epizooties
} 
- Despite the positive EFSA assessment of the consent holders' monitoring reports, we can observe that, to date, the consent holders do not include non-GMO areas that are in practice delegated to the responsibility of the EU-MS (Alacalde et al., 2007; Lecoq et al., 2007; Monsanto Co., 2006, 2009a, b; Tinland, 2008; Tinland et al., 2007; Wandelt, 2007; Windels et al., 2009). Accordingly, several EU-MS have already, or are planning to, launched GS research projects and networks even in those EU-MS with bans on GMOs (Bartsch et al., 2009; Breckling and Reuter, 2006; de Jong, 2010; Gathmann, 2009; Gathmann and Bartsch, 2006; Pascher et al., 2009). This survey of non-GM cropped areas is however of utmost importance as recently shown in China (Lu et al., 2010). Unfortunately, we can again observe that private interests and benefits are supported by public funding when general goods are concerned, as usual in the "Tragedy of Commons" frame (Hardin, 1968; Hardin, 1998).

Most current environmental GS plans focus on changes in ex ante baseline and / or biodiversity assessments, sometimes along with a general approach looking at the effect of agricultural practices (Hintermann et al., 2002; Monkemeyer et al., 2006; Sanvido et al., 2007a; Sanvido et al., 2007b, 2009a; Sanvido et al., 2009b; Schmidt et al., 2009). However, the conceptual framework for environmental GS is far from being both a consensus and a reality. This situation motivated the European Commission to launch a call for proposals in 2010 (KBBE.2011.3.5-01) that address environmental GS and possible standardization (ACRE, 2004; Beismann et al., 2007; EFSA GMO panel, 2006b; Finck et al., 2006; Ostergard et al., 2009; Pascher et al., 2009; Sanvido et al., 2005; Schiemann, 2007; Seitz et al., 2010; Wilhelm et al., 2003; Wilhelm et al., 2009; Wilhelm and Schiemann, 2006).

The main conclusion that can be drawn from the current situation is that, despite the mandatory involvement of GMO consent holders into GMO GS and the monitoring of nonGMO areas, the main effort appears to be supplied by the EU-MS.

However, a number of environmental monitoring procedures are already in place in the EU, several of which partly embrace - episodically or on a longer term - biodiversity, GMO CSM, "epidemio-surveillance", or more general effects of agricultural practices on agroenvironment. In several instances, these monitoring schemes are carried out by citizens in a so-called participatory science. These trends might be correlated with another trend for observing territory from societal and economic viewpoints (Barzman et al., 2005; Bodiguel, 2003; Cardwell and Bodiguel, 2005; Henle et al., 2008). Networks of citizens and/or scientists, as well as enforcement authorities already working on these issues, all have in common (i) a need for long-term studies, (ii) different demands on space and changes over time, (iii) different indicators which (iv) generally have to be reported to national CA and EC, sometimes according to international treaties. But up until now, results appear fragmented, collated in different databases generally without quality assessment or direct connection through a unique Web-based portal or automatic novelty detection capacity (Haggett, 2008).

Nonetheless the environmental liability directive and the right of European citizens to have access to environmental information reinforce the need for gathering these fragmented data (Cardwell, 2010; Ebert and Lahnstein, 2008; European Commission, 1985, 2003b, 2004a, c, 2006c, 2007b).

In the case that GM soybean cultivation would be allowed in the future, there are thus numerous issues that should be fulfilled by consent holders, particularly for herbicide tolerant crops whose uncontrolled use in third countries leads to numerous herbicide resistant weeds and costly companies' based eradication programs (Adams, 2011; Brasher, 2010; Cerdeira and Duke, 2006, 2007). 


\section{Soybean in the EU}

\subsection{A rapid historic overview of the last decades}

In the Dillon round of GATT negotiations (1960-62), the EEC 12 negotiated zero duties on soybeans and several other agricultural products. At the time, soybean was of little importance in international trade with ca 4 MT traded in 1961. Furthermore, there were no varieties of soy available at this time that could be grown in this EU-6. Thus the EU-6 had no producers to protect and found in their interest to keep borders open to soybeans and their products. At that time, pasturages, cereal and some domestic protein rich crops provided most of the necessary feed. That period was the beginning of a drastic change into the European livestock production.

However, the high European internal costs of feed grains forced livestock producers to substitute cheaper soybean meal. In addition to the competition between European feed grains and imported soybean meal, soybean oil competed with domestic vegetable oils such as sunflower oil, olive oil or rapeseed oil, and, when used in margarine, competes with butter. To compete with cheap soybean oil, local oils were subsidized, which was attacked under GATT in 1987. In 1973, a shortage in US soybean exports impacted most of the current EU-MS, including France which was considered as the least soybean dependent EU-MS (Berlan et al., 1977; Hasha, 2002). As maize and soybean compete for both feeding and surface, this kind of shortage is expected to come back with the growing use of maize for bio-ethanol production (Headey, 2011). Several EU-MS attempted to reduce their growing dependence from soybean by national protein plans - but up to now unsuccessfully.

The European cropping of soybean was, up to 2007, restricted to some EU-MS and aimed at food or a few feed specialties (e.g. organic) with most of the production being based in Italy. Among the several reasons why EU is not a soybean producer we can distinguish a relatively unfavorable climate with cool spring and drought early summer, with a Northern predominance, in the EU compared to third countries producing soybean and a relatively high population density with rather small farms and fields. However, several soy varieties are cultivated in Canada and thus soy cropping in the EU-27 would now be possible after appropriate selection of cultivars, provided the seed companies could find some benefit in that selection. This would be probably the case after GM soybean approval for European cultivation.

The EU was in 2007 still under construction and two new countries coming from the implosion of the former soviet bloc entered the EU-25. At its entrance into the EU, Romania officially stopped cropping GM soybean and came back to old varieties of non-GM soybean whose cropping was also not favored by the current European Common Agricultural Policy (CAP; Badea and Pamfil, 2009; Dinu et al., 2010). However, the interest in GM soybean was declining from 1996 to 2002 (Brookes, 2005).

\subsection{Soybean use in the EU}

As most of the crops choices made by farmers over the last decades, soybean cultivation is highly linked to the several changes in CAP. Among those more related to soy cultivation (i.e. linked to oilseed and protein rich crops) we can notice the changes due the Blair House agreement, in 1992, for duty free soybean importation and the Berlin agreement, in 1999, for decreasing aids to oilseeds and open widely the European market to global trade.

${ }^{12}$ Economic European Communities or EU-6 


\begin{tabular}{|c|c|c|c|c|c|}
\hline 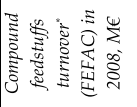 & 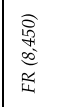 & 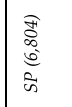 & 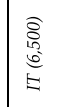 & $\begin{array}{l}\text { 离 } \\
\text { 䞨 } \\
\text { 㟔 }\end{array}$ & 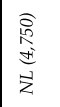 \\
\hline 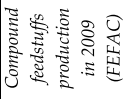 & कि & 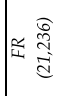 & سू & $\hat{z} \stackrel{\widehat{g}}{\vec{d}}$ & 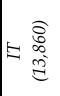 \\
\hline 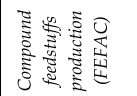 & 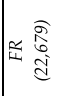 & कि & 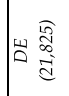 & 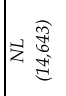 & 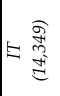 \\
\hline 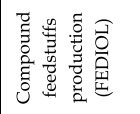 & 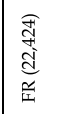 & 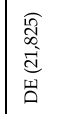 & $\begin{array}{l}\text { क्ते } \\
\text { टे } \\
\text { के }\end{array}$ & 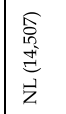 & 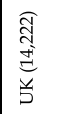 \\
\hline 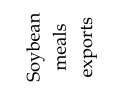 & 光迳 & 㟔 总 & 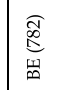 & $\begin{array}{l}\text { 曆 } \\
\text { 尚 }\end{array}$ & $\begin{array}{l}\underset{d}{d} \\
\stackrel{E}{L}\end{array}$ \\
\hline 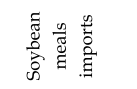 & 责 & 茎 & Wu & 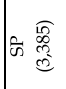 & క \\
\hline 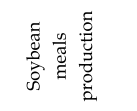 & 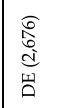 & 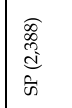 & $\begin{array}{l}\text { 令 } \\
\text { d̃ } \\
\text { Zn }\end{array}$ & 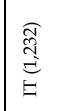 & 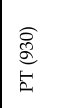 \\
\hline 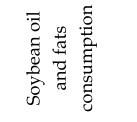 & $\begin{array}{l}\text { 参 } \\
\text { 㟧 }\end{array}$ & $\begin{array}{l}\text { 吕 } \\
\text { 总 } \\
\frac{9}{4}\end{array}$ & 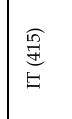 & $\begin{array}{l}\text { E } \\
\text { क् } \\
\text { के }\end{array}$ & $\begin{array}{l}\frac{\sqrt{d}}{d} \\
\text { b̆ }\end{array}$ \\
\hline 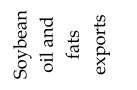 & 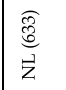 & $\begin{array}{l}\widehat{\widetilde{d}} \\
\overline{\tilde{n}}\end{array}$ & $\begin{array}{l}\text { 今్ } \\
\text { o } \\
\text { 营 }\end{array}$ & 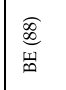 & 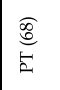 \\
\hline 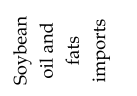 & 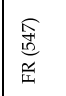 & 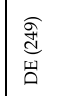 & $\frac{\widehat{d}}{\bar{z}}$ & 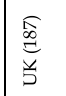 & 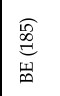 \\
\hline 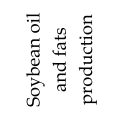 & 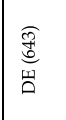 & 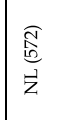 & $\begin{array}{l}\frac{\sigma}{8} \\
\frac{d}{0} \\
\bar{\omega}\end{array}$ & 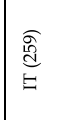 & 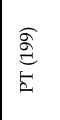 \\
\hline 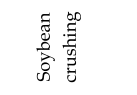 & 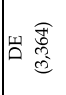 & कि & 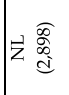 & $\approx$ 突 & $\begin{array}{l}\text { 畣 } \\
\text { 总 } \\
0\end{array}$ \\
\hline 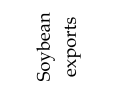 & Z & 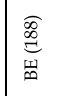 & $\begin{array}{l}\text { 在 } \\
\stackrel{\vec{\omega}}{\omega}\end{array}$ & $\begin{array}{l}\text { 疍 } \\
\text { 㟔 }\end{array}$ & 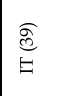 \\
\hline 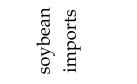 & 方害 & 四垔 & कि & 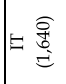 & 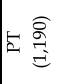 \\
\hline & & & & & \\
\hline
\end{tabular}

With an important increase since 2006 due to the food crisis.

Table 2. 2008 figures of soybeans, oil fats and meals' import, production and processing (sources: Fediol, 2011 and FEFAC, 2011). BE: Belgium; DE: Germany; FR: France; IT: Italy; NL: The Netherlands; PT: Portugal; SP: Spain; SL: Slovenia; UK: United Kingdom. 
In 2006, the EU imported mostly soy beans and also meal. Crushing capacities have been developed in the Netherlands and Germany. As The Netherlands, Germany and Belgium have important harbors to where the most important part of EU imports of soybeans and meals are discharged, a large part of their imports are re-exported either as beans or more generally as meals and oils. Indeed, The Netherlands are currently a net exporter of soy meal toward other EU-MS. However, other European oilseeds compete with soybean. Generally speaking the proportion of rapeseed crushing is in constant increase over the last years, rapeseed crushing having overtaken soy crushing in 2005 due to the use of oilseed rape in European bio-fuels production. The table 2 provides the figures in 2008 of the soy beans, oil, fats and meals production imports and exports for the first top 5 EU-MS.

The table 3 provides a figure of soy beans and meals imports in the EU from 1980 to 2008. As it can be seen, European soy beans and meals imports are relatively stable, when compared to prices and yearly weather variations, since 2004, i.e. with the integration of 10 and then 2 new Member States into the EU in 2004 and 2007, respectively.

\begin{tabular}{|c|c|c|c|c|c|c|c|c|c|c|c|}
\hline & $\begin{array}{c}2008 \\
\text { EU-27 }\end{array}$ & $\begin{array}{c}2007 \\
\text { EU-27 }\end{array}$ & $\begin{array}{c}2006 \\
\text { EU-25 }\end{array}$ & $\begin{array}{c}2005 \\
\text { EU-25 }\end{array}$ & $\begin{array}{c}2004 \\
\text { EU-25 }\end{array}$ & $\begin{array}{c}2003 \\
\text { EU-15 }\end{array}$ & $\begin{array}{c}2002 \\
\text { EU-15 }\end{array}$ & $\begin{array}{c}2001 \\
\text { EU-15 }\end{array}$ & $\begin{array}{c}2000 \\
\text { EU-15 }\end{array}$ & $\begin{array}{c}1990 \\
\text { EU-12 }\end{array}$ & $\begin{array}{c}1980 \\
\text { EU-9 }\end{array}$ \\
\hline $\begin{array}{c}\text { Soy } \\
\text { beans }\end{array}$ & 15,298 & 15,064 & 14,127 & 14,670 & 14,732 & 17,353 & 18,239 & 17,922 & 14,779 & 13,301 & 11,760 \\
\hline $\begin{array}{c}\text { Soy } \\
\text { meals }\end{array}$ & 23,227 & 24,321 & 23,405 & 23,029 & 22,632 & 20,352 & 19,605 & 17,870 & 15,840 & 10,471 & 7,226 \\
\hline
\end{tabular}

Table 3. Imports $(\times 1,000 \mathrm{~T})$ of soy beans and meals in the EU (source: Fediol, 2011).

\subsubsection{Non-food non-feed use}

Compared to the other uses of soybean the use of soybean, with or without chemical changes, in printer inks, as antifoam agent to bio-fuels and cosmetics are currently rather anecdotic (Gelder et al., 2008; Roebroeck, 2002). For instance most of the European sources of bio-fuel rely on oilseed rape. This part will probably increase with the new CAP reform favoring sustainable and environment friendly agriculture and supporting renewable, low carbon emitting energies sources.

\subsubsection{Food use}

Only a few percent of soybean is used for food purposes (Gelder et al., 2008). Lecithin and oil are the main products used in food, the latter being also used in margarine production, together with some specialties such as some kind of yogurts, vegetarian steaks, or the usual Asian specialties such as Tofu, nato (Roebroeck, 2002). Soy milk is mostly imported from Canada, by some worldwide companies.

\subsubsection{Feed use}

Soybean is mostly imported in the EU-27 for compound feedstuffs production (Popp, 2008). With the end, in the 1990's, of European intervention on cereals, which were used with some soy meal for compound feedstuff production, together with the ban of meat-and-bone meal from most of the feedstuffs (in fact meat-and-bone meal, despite being mostly destroyed, continues to be used in feeding short-living animals such as chickens and fish), the European feedstuff industry was looking for another source of cheap source of protein. 
However, despite the end of European aids on cereals the proportion of cereals into compound feed increased since 1995, while the proportion of meals of all origins fluctuated between $30 \mathrm{Mt}$ and $40 \mathrm{Mt}$.

Compound feed consumption in the EU-27 represents ca. $147.6 \mathrm{Mt}$, a quantity thus similar to the US consumption of $149 \mathrm{Mt}$, with a nearly constant percentage of the global consumption over the past decade. This compound feed consumption was accompanied by an increasing production of pig meat and poultry to be compared to a constant beef and veal production, a difference which is mostly due to the entrance of new EU-MS in 2004 and 2007 (FEFAC, 2010; European Commission DG-Agri, 2010). However, the increase in European meat production is parallel to a general trend of decrease (beef, veal, pig) or stagnation (poultry) of European meat consumption. In 2009, the proportion of compound feed for animal rearing again decreased to ca. $30 \%$ of the total feedstuffs quantity which corresponds to a general change into the European livestock production schemes.

The soybean meal is used for all animal feeding, particularly since the ban in 2001 of meatand-bone meals due to the mad-cow / BSE disease, with an exception for organic production or some animals growing under specific signs-of-quality. This important source of protein cannot be fully replaced by fish meal which was another reason for increasing the imports of protein rich commodities. Due to its high content of protein and relative poorness in fat, the soy meal is relatively difficult to replace in poultry, piglets and calves feeding. Alternative sources of protein such as sweet lupine, field pea or rapeseed meal are generally less palatable until the animals reach maturity. This explains the figure of compound feed mostly used for poultry and pig production (FEFAC, 2011). The issue of protein source is of less importance for mature animals and more particularly for cattle.

The origin of imported soybean may depend on EU-MS, for instance France mostly imports soy from Brazil while The Netherlands and Portugal are the top 2 importers of the US exports of soybean (Dahl and House, 2008). Up to 2008, EU was the first destination of exported soybean from USA, Brazil and Argentina. The European protein crops imports represented in 2009 ca. 20 Mha cultivated outside Europe.

However, the development of GM crops in the 3 main exporting countries definitely impeded exports, particularly in the US. Brazil, up to now, took into account the undesirable effect of asynchronous approvals of GM crops on its exports toward the EU (Aramyan et al., 2009a; Aramyan et al., 2009b; Boshnakova et al., 2009; DG AGRI European Commission, 2007; Dobrescu et al., 2009; Konduru, 2008; Stein and Rodriguez-Cerezo, 2009; Stein and Rodriguez-Cerezo, 2010b).

\subsubsection{The animal labeling issue}

As the animals fed with GMOs do not have to be labeled in the EU, most of the feedstuffs in the EU-27 is produced from GM soybean. However several NGO and consumers associations are requesting such animal labeling, a request supported by polls and experimental auctions studies (Kontoleon and Yabe, 2006; Noussair et al., 2004). The EU organic farming threshold of labeling is also of $0.9 \%$ (European Commission, 2007a, 2008a). However, this EU threshold can be superseded by national measures. More generally speaking the EU has numerous signs-of-quality, based, not only on brands as in third countries, but mostly on EC-approved processes or origins. The consumers' reluctance was thus taken into account in production procedures of most of these quality signs by eliminating GMO use into feedstuffs. 
Germany and Austria recently introduced a legislative frame for GMO-free labeling. In these countries the GMO-free threshold complies with the European $0.9 \%$ threshold of fortuitous or technically unavoidable presence of GMO. This labeling is applicable to both vegetal produce and animals reared with "GMO-free" feed.

In another hand, several French producers, such as Poulets de Loué, or retailers, such as Carrefour, or quality signs producers such as Comté cheese, used non-GM (Identity Preserved, at $0.9 \%$ ) soybean since the beginning of the XXIst century but without the possibility of retrieving profits of their efforts (Milanesi, 2008, 2009). In 2009, the French Conseil de la Consommation as well as the Haut Conseil des Biotechnologies (HCB) released recommendations for the creation of a GMO-free supply chain at $0.1 \%$, with, in the latter advice, animal labeling according to 2 thresholds: below $0.1 \%$ and between 0.1 and $0.9 \%$. Despite the fact that the French decree related to GMO-free labeling is so far not published, several producers and retailers took this opportunity, and the further policy change of the French Repression of Fraud services, to label their animals as being reared with less than $0.9 \%$. If the latest HCB recommendation is followed up by the French government, 2 kinds of GMO-free animal labeling would thus prevail in France: "reared with GMO-free feedstuffs below $0.9 \%$ " and "reared with GMO-free feedstuffs below $0.1 \%$ ". The HCB also requested into its recommendation that the French government should precede the implementation by an ex ante socio-economic analysis of the viability of such a GMO-free supply chain at $0.1 \%$. A feasibility study on this request for a ex ante socio-economic analysis is currently ongoing.

However, the availability of non-GM (including GMO content below 0.9\%, IP, and "GMOfree" at $0.1 \%$ or "hard $\mathrm{IP}^{\prime \prime}$ ) soybean is far from being sustainable. Up to 2008, Brazil was the most important exporter of non-GM and GMO-free soy toward EU with negotiated premiums. But the breeding of new soy GM varieties more appropriate to Brazilian climate induced a new increase of GM surfaces in Brazil, particularly in Matto-Grosso with the largest farms and fields (Fok, 2010). Despite the fact that Parana state dedicated a whole harbor to non-GM soy, this state also moved, toward GM soy, particularly for the most weedy fields and by the farmers the less experienced into weed management. The main source of European non-GM soy could thus disappear unless operators facilitate the maintenance of non-GM cropping.

One of the first issues, for maintaining the interest of non-GM cropping, is the rather low level of premium (ca 1/4th of the final one paid by final buyers) received by the Brazilian farmers. The second is that this non-GMO related premium is not discerned by the buyers, such as cooperatives, from other premiums, all premiums being thus provided into a non transparent package of several premiums. The incentive of producing non-GM soy is thus rather low in Brazil despite the fact that the tech fees imposed by the traits' providers may be ca $40 \%$ of the seeds prices (Bonny, 2009; Fok, 2010). According to ABRANGE, a Brazilian association of non-GM farmers, Brazil would be however currently providing $53 \%$ of nonGM soybean while India and China would be providing 18 and 17\%, respectively (Milanesi, 2011). However, these claims are not in line with the observation of the 2009 increase of nonGM soybean in USA, after a decade-long decrease of non-GM soybean areas, due to both more incentive premiums for non-GM beans and increased production costs of GMOs (prices of seeds and herbicide) (Milanesi, 2011).

With premiums, long-term contracts are the second driving force for farmers for maintaining what several authors call market niches (Foster, 2007, 2010). Long-term contracts have thus been established by European producers, such as Poulets de Loué, with or 
without the support of the European GMO-Free regions and Brazilian producers such as the Brazilian ABRANGE association. Generally speaking, the European GMO-free regions' network supports their producers into their search for long-term supply of "cheap" non-GM soy.

The premiums ranged from an average of 16 US\$ in 2004 to ca. 70 US\$ in 2009 for US farmers (Foster, 2010; Milanesi, 2011). While it is generally difficult to determine the premiums fluctuations over the year due to the confidentiality of the contracts, the changes observed into the non-GM soybean market of Tokyo show a general trend of a $10 \%$ premium over the GM soybean, with of course important peaks up to $40 \%$ in 2008 due to both the food crisis and an decrease of US 2007/08 soybean cropped surface in that year (Foster, 2010; Headey, 2011). Compared to the "only" 83\% of soybean price increase over 30 years, such premiums could thus be very incentive, particularly when linked to long-term contracts.

The increase of price of compound feed due to this non-GM soy would be of less than $3 \%$ (Gryson and Eeckhout, 2011). Since feed cost represents ca. $77 \%$ of price of chickens, this would induce a final small increase of some cents per chickens' kilo (Milanesi, 2008, 2009).

Most of the European imports of both GM and non-GM soy are through the main commodities traders namely ADM, Bunge, Cargill and Louis Dreyfus (Green and Hervé, 2006). However, as these traders advertised they were facing a shortage of non-GM soy, several new SMEs, such as Solteam, are currently developing their own import network to provide European feed producers with non-GM commodities. With the growing surfaces of GM soybean in Brazil, alternative sources of non-GM soy are actively looked for beside longterm contracts and premiums use for sustaining the availability of American non-GM soy.

However, the main forthcoming issue might be the availability of low cost non-GM soybean varieties both in third countries and EU-MS (Milanesi, 2011; Then and Stolze, 2010). As currently observed, the availability of non-GM seeds is decreasing with a few new varieties being commercially released. Accordingly, old non-GM seeds cannot compete with new GM varieties what can explain, together with a lack of support of oilseeds by the European CAP, the dramatic decrease in yields and total production observed in Romania at its entrance in 2007 in the EU-27 (Dinu et al., 2010). Despite the fact that new but small plant breeder and seeds sellers (such as eMerge a Cargill subsidiary) are appearing, their ability to access to soybean germplams is questionable as private sector is focusing on GM varieties and public research is focused on germplasms (Heisey et al., 2005; Heisey et al., 2001; Naeve et al., 2010; Orf, 2004). The availability by the big seeds companies of non-GM soy varieties will highly depend on their forward or backward breeding strategies (Milanesi, 2011).

It may worth noting that while traders such as Cargill are developing such seeds companies which will help them to maintain the non-GM flows towards several importing countries: competing on global commodities trade does not mean, for such companies, excluding higher added value market niches. In the meantime, participatory breeding of non-GM soy varieties is also developing as observed for numerous other crops (Bellon and Morris, 2002; Desclaux et al., 2008; Smale, 1998). As noted by several authors, this availability of several kind of varieties is necessary for developing the segmented markets requested by farmers, retailers and consumers (Elbehri, 2007).

\subsection{Soybean cultivation in the EU-27}

As noticed by a recent motion of the European parliament, protein rich crop production occupies only $3 \%$ of EU-27 arable land and supplies only ca $30 \%$ of protein crops consumed 
as animal feed (LMC International, 2009a, b; Häusling, 2011). Table 4 provides figures on some EU-MS surfaces of soy cultivation (Eurostat, 2011).

With the Agenda 2000 CAP reform, aid to European farmers became decoupled, i.e. aid were no longer received for oilseeds production, nor related to yields. There is thus no more European intervention for buying, export subsidizing or other market support available for oilseeds in the EU-27. Moreover, agricultural aid is now rather linked to environment preservation and sustainable agriculture, the second pillar of the new CAP, together with social criteria (Krautgartner et al., 2010b). These drastic changes into the European CAP could lead to drastic changes during the next years in the European cultivations' schemes.

\begin{tabular}{|l|c|c|c|c|c|c|c|c|c|c|c|c|}
\hline & 2010 & 2009 & 2008 & 2007 & 2006 & 2005 & 2004 & 2003 & 2002 & 2001 & 2000 & 1999 \\
\hline Italy & 159 & 134.7 & 107.8 & 130.3 & 177.9 & 152.3 & 150.4 & 152.1 & 152 & 233.5 & 252.6 & 246.5 \\
\hline Romania & 65.2 & 48.8 & 49.9 & $133.2^{13}$ & 190.8 & 143.1 & 121.3 & 128.8 & 71.8 & 44.8 & 117. & 99.8 \\
\hline France & 50.9 & 43.7 & 21.8 & 32.4 & 45.3 & 57.4 & 58.6 & 80.7 & 74.8 & 120.9 & 77.7 & 98.2 \\
\hline Austria & 34.4 & 25.3 & 18.4 & 20.2 & 25 & 21.4 & 17.9 & 15.5 & 14 & 16.3 & 15.5 & 18.5 \\
\hline Hungary & 33.5 & 31.5 & 29 & 32.9 & 35.9 & 33.6 & $27.3^{14}$ & 30.3 & 25 & 20.6 & 22.2 & 32.2 \\
\hline
\end{tabular}

Table 4 . Surface $(\times 1,000 \mathrm{ha})$ of soybean cultivation in the top 5 EU-MS (Eurostat, 2011).

In the Western part of the EU-27, soy cultivation attempts to satisfy the needs of high added values supplies such as food and meat production under signs-of-quality. However, in spite of several "protein plans", soy is still not considered as an important European crop.

While Western Europe was poorly considering soybean cultivation yet started to import soybean since ca. the second decade of the XXth century, the former USSR developed a soybean breeding institute since the beginning of this last century. As a result of Russian research, several soybean varieties were developed for the former Soviet bloc. An important area of soybean cropping is thus done in the eastern part of Europe, around the southern Danube basin, in particular in Romania, but also in Bulgaria and Hungary. As another example of such Soviet soybean production, and thus of varieties adapted to the European climate, Ukraine and Russia were cropping in 2006 725,000 and 810,100 ha, respectively (Otiman et al., 2008). However, Romania was the only country to extensively grow GM soybean over ca 137,000 ha for feedstuff production but with yield per ha nearly $2 / 3^{\text {rd }}$ of the ones of USA, Brazil and Argentine. While irrigation is important for increasing the yield, it is also highly probable that the GM varieties were not fully adapted to the European eastern conditions.

Since its entrance in the EU in 2007, Romania stopped cultivating of GM soybean, but started with the MON 810 GM maize (Badea and Pamfil, 2009). Since that time Romanian farmers claim that after a period of self-sufficiency in feed, they had to import again soybean for livestock (Otiman et al., 2008). However, the decrease in soybean cultivation is more probably linked to the absence of European subsidies to soybean cultivation and a return to old, less productive, non-GM soy varieties. Romanian farmers are thus among those pushing to force the European approval of GM soybean cultivation, whose dossier is currently in the European approval pipeline. This may also be explained by the existence, in several Central and Eastern European Countries (CEEC), of large, corporate, farms up to 20,000 ha, inherited from the reforms after the Soviet bloc implosion, which face the same

\footnotetext{
13 Integration into the EU

${ }^{14}$ Integration into the EU
} 
weed management issue as the large farms of third countries (Csaki and Lerman, 1997; Eurostat. European Commission, 2010; Pouliquen, 2001).

Coexistence between GM and non-GM soy would probably not be an issue as soy is mostly autogamous as soon as the European seeds' threshold for non-GM seeds is defined (Roebroeck, 2002). However, case specific monitoring will be an important and costly workload for herbicide tolerant soybean cropping in order to avoid the issues of herbicide resistant weeds observed in the USA and eradication programs paid by companies (Brasher, 2010; Owen et al., 2010; Owen, 2009; Roberson, 2010).

As observed by most of the scholars and policy makers, European farming is highly dependent on CAP (Carlier et al., 2010; Cavaillès, 2009). Accordingly, European soybean cropping is currently only driven by global market prices. As finally observed by a recent EC sponsored study, a soybean shortage, such as the last US one in 2007, and thus an increase into soybean prices might induce reallocation of European arable surfaces toward soybean cultivation and probably allow several EU-MS to become self-sufficient. In this way, soybean might be considered as an opportunistic crop by European farmers driven by global soy prices, particularly for its non-GM counterpart. However, the European farmers have to "internalize" soybean cultivation into their agricultural practices and productions particularly in the EU-MS of Western Europe where soybean is not a familiar crop. For instance, farmers of Alsace region in France recently introduced a maize / soybean rotation as a tool to fighting Western corn rootworm. This "internalization" of rotation with soybean into maize culture may be rapid as the French government recently issued a decree making rotation mandatory.

Several recent changes in the CAP have to be kept in mind. In particular due to substantial reductions of aid in several agricultural sectors, European farmers have a closer look on the impact of the global commodities market on their sales prices with an increased trend toward crops' futures markets. In the meantime, farmers need to have new considerations toward the environment; the reduction into available chemicals for pest fighting, the carbon footprint, the multi-functionality of agriculture, etc. (Commission, 2006; European Commission, 2009d; Kaditi and Swinnen, 2006).

It is thus predictable that soybean cropping will differ from East to West among the EU-27, with probably GM crops in the eastern part, which is comparable to the gradient of sensitivity to GMO issues as observed for consumers (Consumerchoice Consortium, 2008).

\subsection{Alternatives to imported soybean}

Two considerations structure the soy importation issue: the first considering feedstuff production with GM soy and the second considering the use of non-GM soybean. Indeed alternative protein-rich crops did not succeed in the previous national or European "protein plans" and are less palatable to poultry and young pigs.

\subsubsection{The issue of asynchronous approvals}

As previously said, EU generally takes more time for approving GMO than several third countries, in part due to incomplete dossiers but probably also because of the EU-MS unclear economic interest of GM crops (European Commission, 2011).

The import of GM soybean is thus affected by this approval status as reported by numerous reports (ADAS ltd (for DEFRA feed import project), 2008; Aramyan et al., 2009a; Aramyan et al., 2009b; DG AGRI European Commission, 2007; Nowicki et al., 2010; Stein and Rodriguez- 
Cerezo, 2009; Stein and Rodriguez-Cerezo, 2010b; Stein and Rodríguez-Cerezo, 2009; Tallage, 2010). All these reports concluded there is no alternatives to imported soybeans and meals, and thus recommended establishing a specific Low Level Presence threshold for EU unapproved GMOs to avoid any shortage in soybean which could hamper European livestock competitiveness, a recommendation recently officially taken in consideration by the EC by establishing a LLP threshold for EU unapproved GMOs dedicated to feed.

However, how reliable are these converging predictions? It might be helpful to have some insights on some recent reports on such issues of feed shortage in the EU-27. Are there some biases in those studies which are almost all based on modeling of feed use?

Models are clearly needed for simplifying complex situation and decision taking. In that way, it is thus understandable that models are used for forecasting international trade and soybean use in feedstuff production. However the choice of model or postulates, such as linear regression and "general equilibrium" instead of alternative is not neutral. Besides this essential questioning, common to all modeling issues, we will just examine some contextual questions.

- The first observation we can make is that those studies were carried out with limited funding in short time; thus impeding long studies and collective, contradictory expertise. Another problem is the use of very recently developed models, used by the EC without having been clearly in depth validated, or used out their scope, e.g. to foresee future trends while developed to analyze the past (Harrell, 2001). Some of these models were "validated" by discarding some crops in some parts of the evaluation but taking them into account into other evaluation parts. As these crops are used as adjustment variables in substitution strategies for low-price compound feedstuffs production, the validity of such models is highly questionable. The same issue of validating models applies to models attempting to merge ecological and CAP issues. It is finally rather surprising to read in a report about the development of a model, that one of the main goals was to simplify the yearly feeding of the model due to some lack of personal in the corresponding European Commission service. Avoiding complexity and simplifying the life of European personal does not help make sound policy.

- The large use of modeling is the expression of a general disinterest of economists for empirical studies and a preference toward modeling. This disinterest of economist scholars or consultants is due to (i) the difficulties to retrieve accurate information from companies and interviews, (ii) the duration necessary for establishing their own databases, together with (iii) a higher ranking in peer-reviewed journals for models, rather than for empirical data. There is thus a fundamental lack of sound, scholarlyestablished empirical data, i.e. not provided only by the companies in charge of feed production, before founding policy on models.

- A "business-as-usual" trend, i.e. a relative poorness in investigated scenarios and generally speaking in perspectives and alternatives. All considered scenarios take as read the requests of feed producers, i.e. the need for soybean and more generally proteins imports; just as previously cereals and then meat-and-bone were supposed to supply all needed proteins. This "business-as-usual" trend may in great part be explained by the power of lobbies, some kind of blindness, i.e. lack of prospective. However, it is generally recognized that a mass market is always turning into a market of niches and that EU is among the largest provider of market niches (Anderson, 2006). Such models are thus inter-alia not referring to market differentiation, European landscape use, consumers welfare, region competitiveness and ecological issues as 
requested by the second pillar of the new CAP (Hermans et al., 2010; Kissinger and Rees, 2010; Konefal and Busch, 2010; van Delden et al., 2010). As outlined by Konefal and Bush, maize and soybean market standardization also introduced a multiplicity of segmented markets which were not taken into these models.

- Short and over-simplified studies, as generally the policy makers need rapid results and the academic community is rather slow to mobilize for participating in such applied work. Thus calls for this type of studies are generally awarded by consultants' cabinets or by the few scientists having already worked on that issue and thus able to "reinvest" their initial work. Work is thus mostly desk-search with several biases, such as a more difficult access to the scientific literature, a large use of "Google" which highlights URL according to a Google ranking algorithm mostly based on the number of external links or sponsorship, thus a way of working which favors industry and lobbies reports and sites.

- Group "consanguinity": such a strong relationship between sponsors, for instance a technical officer in charge of supervising an European study, originating from a European institute, whose recent reports all biased in the same way the effect of EU unapproved GMOs on feed availability. This first type of consanguinity is then reinforced by the tenders who have been chosen after a call for tenders. In most of the instances, the scientists have published reports in the same way, e.g. the dramatic effect of EU unapproved GMOs on feed availability. Reinvesting initial work is clearly not the best way for sound prospective in comparison of a collective and contradictory expertise.

- Influence of working environment. Indeed several studies were carried out in an EU country highly depending on feedstuffs ingredients importations, and further reexportations, which may hamper the independence of viewpoint of the scientists and criteria retained for the scenarios. This may also be linked to previous studies funded by the feed industry which may influence the viewpoints and future results. Again, it would be necessary to amplify the panel of viewpoints, e.g. with scientists from countries with different production schemes. By not taking into consideration the socioeconomic context and history of some scientists, the EU is decreasing its chances to find a systemic and long-term solution.

Taken altogether, these considerations of the studies and modeling context show the limits of the available data and predictions. This militates for more scholar-driven, long-term, multidisciplinary and with people sharing different viewpoints about futures of agriculture into collective expertise using also different modeling and postulates bases. Rapid, biased studies for a very complex matter highly influenced by both uncontrolled events, (such as seasonal incidents, or policy controlled issues, such as the disappearance of fallows in the new CAP, further cultivable areas reallocations and integration of new players), are not the best conditions for forecasting the future of European agriculture needs.

The users, i.e. policy makers, should be aware of the strengths and weaknesses of models used by the technical officers, what is generally not the case in the reports provided to the policy makers or media (van Tongeren et al., 2001). To conclude, the over-simplified models, developed moreover under detrimental contextual influences, have drastic limitations for forecasting trade and supply chains trends but are routinely used and dramatically impact the European policy without sound "scientific" ground-bases. These observations together with other not reported in this paper show that the EC was in fact over the last years 
attempting to "scientifically" legitimate previous political decisions for "smoothing" global trade issues.

\subsubsection{Perspectives}

In spite of a careful survey of European scientific and grey literature on alternatives to GM soy, almost no one Western EU stakeholder involved into meat production is currently considering soybean cultivation in the EU as a solution. Beside some recommendations to come back to pasturage for cattle, the general trend in compound feedstuff production is a larger incorporation of European non-GM rapeseed meal as it can be seen in the statistics of Fediol as a by-product of European bio-fuel production. Substitution is thus generally retained in national schemes for non-GM soy use. However new Eastern EU-MS have a long tradition of soy cultivation with some very large farms which might, in the 'business-asusual" trend benefit from GM, or non-GM, soy cultivation.

\subsubsection{Domestic substitution to imported soybean}

Two ways of substitution of imported soybean have to be considered: firstly, the European cultivation of soy, as this protein-rich feed is difficult to substitute in feedstuff of several young animals and, secondly, the replacement of soybean by some other protein-rich crop for adults or some young animals.

As observed in several studies the trend over the last decade to use low-price soybean and soy meal induced a clear disaffection of plant breeding companies for leguminous fodder crops (alfalfa, clover, etc.) and several protein-rich crops (field pea, sweet lupine, etc.) due to their small volumes and a constant decrease of cultivation over the last decade (European Parliament. Directorate-General for Internal Policies, 2010; LMC International, 2009a, b; Häusling, 2011). Moreover, public research programs on such European substitutes to soybean declined over the 3 last decades. As a example of such general decline, domestic leguminous crops to be incorporated into feed dropped in France from 11\% in 1991 toward $2.5 \%$ in 2006, despite CAP subsidies of field pea, field bean and lupine (European Commission, 2009c). If some studies are currently ongoing, for instance on the use of lupine and pea for poultry, there is a lack of European research on substituting soybean by domestic protein-rich crops which however present the interest of currently being non-GM (Laudadio et al., 2009; Häusling, 2011).

Several changes in the CAP such as the "20-20-20 in 2020" objectives (reduction of $20 \%$ of emissions from 1990, 20\% share of energy consumption from renewable sources and $20 \%$ improvement in energy efficiency by 2020) conducted to an increase of rapeseed oil production for bio-fuels and thus of alternative meal, at least for some livestock.

Under the Blair House agreement, oilseeds plantings were limited to an adjusted Maximum Guaranteed Area for producers benefiting from crop specific oilseeds payments. This limited the EU oilseeds production area and penalized overproduction till the 2003 renegotiation of Blair House agreement. Finally, with the Agenda 2000, the CAP relies on 2 pillars: the market and income policy (first pillar) and the sustainable development of rural areas (second pillar). Since 2010, the producers are free of the hectare limits set out by Blair House agreement. Additionally, the disappearance of European mandatory fallows is freeing new arable surfaces for, current or new, long-term or opportunistic cultivations.

As the 2003 CAP reform (linked to renegotiation of Blair House agreement) brings greater consideration to environmental integration we may expect several changes, in particular about soybean whose production in Brazil is criticized due to deforestation, an important 
use of chemicals and social impacts (Carlier et al., 2010). The recent reduced European interest for biofuels production in the EU due to a contrasted carbon footprint, as well as a possible effect on food prices could also free agricultural surfaces for soy opportunistic cultivation. However, studies on soybean use in cow feeding show that soy might have less environment impacting than rapeseed (Lehuger et al., 2009). The new CAP which embraces more environmental considerations may thus face new issues in the balance of environmental footprint and might let European prefer importing soy.

After a ban of about a decade, several lobbyists are pushing the reintroduction of meat-andbone meal, probably the richest protein source. For instance in 2002, 220,000T were estimated equivalent to 503,000 T of soy meal. The European dependence onto imported soy could thus be dramatically decreased if meat-and-bone is safely re-incorporated into feedstuffs. However, the acceptance of European consumers of such a reintroduction is far from being obvious following the 1990' ' mad-cow disease scandal.

CAP Health check in 2008 reduced again aids to cereals opening the opportunity to grow more oilseeds including soybean despite a previous EU support to protein-rich crops such as field pea, field bean and lupine.

Surprisingly, in all alternatives to soybean imports even though by NGO or organic farmers, no one proposed cultivation of soybean as protein sources alternatives, at least for conventional livestock (Billon et al., 2009; Confédération paysanne, 2002). However, production of European soybean showed in 2009 a $12.4 \%$ increase which demonstrates the opportunism of European farmers in front of high trade prices of the 2008/2009 food crisis (Krautgartner et al., 2010a). Such an alternative of soy cropping instead of imports should be more effectively considered in EU-MS, even though it looks difficult to dedicate ca. 20 Millions of European hectares to soy, the equivalent in surfaces of currently imported soy (see above).

The recent entrance of several new EU-MS, with a past of soybean crops and some very large corporate farms, could also accompany this trend of growing more soybean in the EU. Interviewed Spanish representatives agreed that Spain could grow soybean, be these GM or not, as soon as the prices would be of interest. Additionally, the fight against the Western corn rootworm (Diabrotica virgifera virgifera) in French maize monocultures was successful when introducing soybean into a newly implemented rotation, a choice of crop made in function of cropping practices and apparatus compatibility. Together with the environmental and economic interest of introducing a leguminous plant into rotations and the more general European request of reducing chemicals in cultivation, the interest of maize monoculture is questionable when we consider that the infected area ${ }^{15}$ covers most of the Central and Eastern European Countries. Finally, the current trend of increase of petrol and thus of nitrogen fertilizer prices also favors reintroduction of leguminous crops into rotation.

In addition to an increasing part of local, pasture based and on-farm production for both "conventional" and under signs-of-quality meat production, the European soybean dependence might thus drastically decrease at least for bovine animals. Soybean imports would then mostly depend on intensive livestock production such as poultry and probably pig.

Altogether, these several observations show a balanced approach of European farmers toward the global market and an important dependence of EU farmers to CAP. As long as soybean and soy meal prices are low, there is no interest for European farmers to enter the

${ }^{15} \mathrm{http}$ // / extension.entm.purdue.edu/wcr/images/pdf/2010/EUROPEMap2010.pdf 
very competitive commodities market. But all occasions can be taken to improve their niche markets of soy be this GM or non-GM.

\subsubsection{Alternative sources of non-GM soy}

With the growing trend to label animals reared on non-GM feed, availability of non-GM soy is of a growing interest for livestock producers. With the increased cropping of GM soy in exporting countries, alternative sources of non-GM soy are thus actively looked for by European importers.

Since the 2008 issue of Chinese organic soy meal spiked with melamine, The Peoples' Republic of China is no longer considered as a reliable source of non-GM soy despite recent claims of its interest for this country (Anonymous, 2010; Hansen et al., 2007; Takada, 2010). China is the most important importer of soybean and this expected to continue (Taylor and Koo, 2010). As numerous GM crops are under development in China together with a growing request of soy for livestock production, we may expect this country may rapidly cease to be a putative exporter of non-GM soybean. Indeed, India is currently a new source of non-GM soy for certain European traders and has been identified as such by US surveys (Ash, 2011).

This current relative shortage of non-GM $(<0.9 \%)$ or GMO-free $(<0.1 \%)$ soybean could be an opportunity for European soy producers, provided they find more incentives to grow soy. The new CAP trend considering more environmental issues might favor such changes into the European farmers practices. Integrating crops rotations with leguminous crops, for decreasing the use of costly fertilizers and fighting some pests such as the expending Western corn root worm, would be additional causes of such practices' changes with premiums and long-term contracts for non-GM productions,.

Beside a new consideration of soybean into crop rotation in Western EU or an increase of soy surfaces in EU-MS cultivating soy for market niches, the European soy status may also change by the integration in 2007 of Central and Eastern European countries such as Romania with a past and a future wish of soybean cultivation. The move of these countries, some cases having very large corporate farms, toward GM or non-GM soy cultivation will greatly depend on non-GM demand, premiums and long-term contracts as well as the volatility of GM soy commodities' prices.

\section{Conclusion}

Europe is so far highly dependent on protein importations for compound feedstuffs production particularly of soy for young animal production, poultry and pigs. However, several factors may lead to an increased soybean production in the EU over the next decade. Among the several reasons for such an increase are societal considerations such as carbon footprint of imported soybean, development of market niches - be these or not GMO-free due to animal labeling - entrance of new EU-MS with a past of soybean cropping as well as a general increase of American exports toward China inducing tensions on prices particularly for poultry and pig feeding.

Soybean cropping would however probably be considered as an opportunistic European crop due to e.g. rotation for fighting corn rootworm which is prevalent in Central and Eastern EU and extending into the Western area, continuous rises in nitrogen fertilizer prices, a persistent ban of meat-and-bones meal as well as an absence of alternative European protein-rich crops. 
As the cultivations are rapidly adjusted to the market requests, there is thus not an issue of soybean supply per se but an issue of importation of soybean at the lowest prices for intensive livestock production. Such issue of competitiveness of European livestock drove the EC to introduce a "technical solution" to EU unapproved GMOs, i.e. a LLP threshold, for feed, which might impact food supply chains since segregating of food and feed is difficult.

At the same time, the need for a larger use of bio-fuels increased the production of oilseed rape in Europe which in counterpart decreased the imports of soybeans. It is currently difficult to determine what would be the future of such by-products of bio-fuels as the European policy bio-fuels appears to be changing due to new calculations of their carbon footprint and the need for "feeding the world". Such trend to develop domestic bio-fuels will probably impact European soy imports and cultivations.

After several shortages in the 1970s and 2000s, the current increases in feed and food commodities' prices after the 2007-2008 food crisis militates for an European alimentary sovereignty due in particular to the impact of the increasing living standards of emerging countries and thus of protein-rich feedstuffs.

Environmental, sustainability and social criteria newly incorporated into the European agricultural aids frame will probably push domestic oilseed production, including soybean and jeopardize oilseeds imports. The main driver of European livestock production and soy imports will also depend on the possible extension among EU-MS of the labeling of animals reared with GMO-free feed.

By the different past histories of Western and Eastern parts of the EU-27, it is also to be expected that the soy cropping strategies, i.e. the choice between GM and non-GM soy cultivation, will differ between the two. The lowest sensitivity of Eastern consumers to GM food and cultivation could facilitate the implementation of GM soy in the Eastern part of the EU, while non-GM soy might develop in the Western part of the EU. Such search for a European "sovereignty" is in line with the development of numerous markets niches, a usual counterpart to a more and more standardized and global trade.

Generally speaking, the recent initiative of the EC for establishing a LLP threshold for feed did not take into consideration the change of paradigm i.e. the European move from an "economy of offer" toward an "economy of demand" nor the difficulties to segregate food and feed commodities.

\section{Note added in proof}

As this chapter was in proof reading, EFSA published its final version of PMEM (EFSA GMO Panel, 2011) and the EC published the LLP related regulation (European Commission, 2011).

\section{References}

ACRE (2004). ACRE Guidance Note 16. Guidance on best practice in the design of postmarket monitoring plans in submissions to the Advisory Committee on Releases to the environment. Guidance for applicants seeking permission to release genetically modified crops into the environment (under Directive 2001/18/EC), 21 p.

Adams, S. (2011). Dow AgriSciences, MU researcher develop a way to control "superweed". Available at:

http:/ / munews.missouri.edu/news-releases/2011/0121-dow-agrisciences-muresearcher-develop-a-way-to-control-\%E2\%80\%9Csuperweed $\%$ E2\%80\%9D / 
ADAS Ltd. (for DEFRA feed import project) (2008). What is the potential to replace imported soya, miaze and maize by-products with other feeds in livestock diets?, ADAS. Ltd, ed. (DEFRA, UK), $30 \mathrm{p}$.

Alacalde, E., Amijee, F., Blache, G., Bremer, C., Fernandez, S., Garcia-Alonso, M., Holt, K., Legris, G., Novillo, C., Schlotter, P., et al. (2007). Insect resistance monitoring for Bt maize cultivation in the EU: Proposal from the industry IRM working group. Journal Fur Verbraucherschutz Und Lebensmittelsicherheit-Journal of Consumer Protection and Food Safety, 2, pp. 47-49.

Alderborn, A., Sundstrom, J., Soeria-Atmadja, D., Sandberg, M., Andersson, H.C., and Hammerling, U. (2010). Genetically modified plants for non-food or non-feed purposes: Straightforward screening for their appearance in food and feed. Food and Chemical Toxicology 48, pp. 453-464.

Anderson, C. (2006). The long tail: why the future of business is selling less of more (Random House / Hyperion).

Anonymous (2010). Soybeans to go non-GM. In China Business News. Available at: http://cnbusinessnews.com/soybeans-to-go-non-gm/

APHIS News release (2010). USDA announces availability of biotechnology quality management system audit tandard and evaluation of comments. Available at: http://www.aphis.usda.gov/biotechnology/news_bqms.shtml

Aramyan, L.H., van Wagenberg, C.P.A., and Backus, G.B.C. (2009a). Impact of unapproved genetically modified soybean on the EU feed industry (Wageningen University, $\mathrm{NL}), 14 \mathrm{p}$.

Aramyan, L.H., Wagenberg, C.P.A.v., and Backus, G.B.C. (2009b). EU policy on GM soy. Tolerance threshold and asynchronic approval. Report 2009-052, $46 \mathrm{p}$.

Ash, M. (2011). Oil Crops Outlook 2011. In A report from the Economic Research Service, U. ERS, ed., 16 p.

Badea, E.M., and Pamfil, D. (2009). The status of agricultural biotechnology and biosafety in Romania. Bulletin of University of Agricultural Sciences and Veterinary Medicine ClujNapoca Animal Science and Biotechnologies, 66, pp. 8-15.

Bakshi, A. (2003). Potential adverse health effects of genetically modified crops. Journal of Toxicology and Environmental Health-Part B-Critical Reviews 6, pp. 211-225.

Bartsch, D., Bigler, F., Castanera, P., Gathmann, A., Gielkens, M., Hartley, S., Lheureux, K., Renckens, S., Schiemann, J., Sweet, J., et al. (2006a). Concepts for general surveillance of genetically modified (GM) plants: the EFSA position. Journal fur Verbraucherschutz und Lebensmittelsicherheit 1, pp. 15-20.

Bartsch, D., Bigler, F., Castanera, P., Gathmann, A., Gielkens, M., Hartley, S., Lheureux, K., Renckens, S., Schiemann, J., Sweet, J., et al. (2006b). The EFSA opinion on postmarket environmental monitoring of GM plants. The 9th International Symposium on the Biosafety of Genetically Modified Organisms, Jeju Island, Korea, 24-29 September, 2006: biosafety research and environmental risk assessment, pp. 159167.

Bartsch, D., Buhk, H.-J., Engel, K.-H., Ewen, C., Flachowsky, G., Gathmann, A., Heinze, P., Koziolek, C., Leggewie, G., Meisner, A., et al. (2009). BEETLE. Long-term effects of genetically modified crops on health and the environment (including biodiversity): Prioritisation of potential risks and delimitation of uncertainties. Executive summary and main report (Berlin, DE), $133 \mathrm{p}$. 
Bartsch, D., Gathmann, A., Hartley, S., Hendriksen, N.B., Hails, R., Lheureux, K., Kiss, J., Mesdagh, S., Neemann, G., Perry, J., et al. (2007). First EFSA experiences with monitoring plans. Journal Fur Verbraucherschutz Und LebensmittelsicherheitJournal of Consumer Protection and Food Safety 2, pp. 33-36.

Barzman, M., Caron, P., Passouant, M., and Tonneau, J.P. (2005). Observatoire Agriculture et Territoires. Etude pour la définition d'une méthode de mise en place d'observatoires, $64 \mathrm{p}$. Available at : http://agriculture.gouv.fr/IMG/pdf/observatoire_rapport_final.pdf

Beckie, H.J., Hall, L.M., Simard, M.J., Leeson, J.Y., and Willenborg, C.J. (2010). A framework for postrelease environmental monitoring of second-generation crops with novel traits. Crop Science, 50, pp. 1587-1604.

Beismann, H., Finck, M., and Seitz, H. (2007). Standardisation of methods for GMO Monitoring on a European level. Journal Fur Verbraucherschutz Und Lebensmittelsicherheit-Journal of Consumer Protection and Food Safety, 2, pp. 76-78.

Beissner, L., Wilhelm, R., and Schiemann, J. (2006). Current research activities to develop and test questionnaires as a tool for the General Surveillance of important crop plants. Journal fur Verbraucherschutz und Lebensmittelsicherheit-Journal of Consumer Protection and Food Safety, 1, pp. 95-97.

Bellon, M.R., and Morris, M.L. (2002). Linking global and local approaches to agricultural technology development: the role of participatory plant breeding research in the CGIAR. In Economics working paper 02- 03, $30 \mathrm{p}$.

Berlan, J.-P., Bertrand, J.-P., and Lebas, L. (1977). The growth of the American 'soybean complex'. European Review of Agricultural Economics, 4, pp. 395-416.

Billon, A., Neyroumande, E., and Deshayes, C. (2009). Vers plus d'indépendance en soja d'importation pour l'alimentation animale en Europe - cas de la France, W.W.F. ENESAD, ed. (Dijon, France, ENESAD, WWF France), 49 p. Available at: http://www.wwf.fr/content/download/2687/20819/version/1/file/rapport+sub stitution+au+soja+complet+2.pdf

Birthal, P.S., Rao, P.P., Nigam, S.N., Bantilan, M.C.S., and Bhagavatula, S. (2010). Groundnut and soybean economies of Asia. Facts, trends and outlook, I.I.C.R.I.f.t.S.-A. Tropics), ed. (Patancheru 502 324, Andra Pradesh, India, ICRISAT), 92 p. Available at: http://dspace.icrisat.ac.in/bitstream/10731/3648/1/rso-gn-sbean-asia.pdf

Bock, A.K., Lheureux, K., Libeau-Dulos, M., Nilsagard, H., and Rodriguez-Cerezo, E. (2002). Scenarios for co-existence of genetically modified, conventional and organic crops in European agriculture. EUR 20394EN, xi +133 p. Available at: http://ftp.jrc.es/EURdoc/eur20394en.pdf

Bodiguel, L. (2003). A way to establish the multifunctional agriculture: the notion of territory. Economie Rurale, pp. 61-75.

Bonny, S. (2008). How have opinions about GMOs changed over time? The situation in the European Union and the USA. CAB Reviews: Perspectives in Agriculture, Veterinary Science, Nutrition and Natural Resources, 3, pp. 1-17.

Bonny, S. (2009). Taking stock of the world market in transgenic seeds. In 13th ICABR conference The emerging bio-economy (Ravello, Italy).

Bontemps, A., Bourguet, D., Pelozuelo, L., Bethenod, M.T., and Ponsard, S. (2004). Managing the evolution of Bacillus thuringiensis resistance in natural populations of the European corn borer, Ostrinia nubilalis: host plant, host race and pherotype of 
adult males at aggregation sites. Proceedings of the Royal Society of London Series BBiological Sciences, 271, pp. 2179-2185.

Boshnakova, M., Dobrescu, M., Flach, B., Henard, M.-C., Krautgartner, R., Lieberz, S., and the group of FAS oilseeds specialists in the EU. (2009). EU-27. Oilseeds crop update - U.S. soybean exports to EU threatened. In EU-27, U.F.A. Service, ed. (Vienna, Austria, USDA GAIN), 11 p. Available at:

http:/ / gain.fas.usda.gov / Recent $\% 20$ GAIN\%20Publications/Oilseeds $\% 20$ Crop $\% 20$ Update $\% 20 \% 20$ U.S.\%20Soybean\%20Exports\%20to\%20EU\%20Threatened_Vienna_ EU-27_8-12-2009.pdf

Bourguet, D. (2004). Resistance to Bacillus thuringiensis toxins in the European corn borer: what chance for Bt maize? Physiological Entomology, 29, pp. 251-256.

Brasher, P. (2010). New weed strategies needed, scientists say. CheckBiotech. Available at: http://checkbiotech.org/node/29440/edit

Breckling, B., and Reuter, H. (2006). General surveillance of genetically modified organisms the importance of expected and unexpected environmental effects. Journal für Verbraucherschutz und Lebensmittelsicherheit, 1, pp. 72-74.

Brookes G. (2005). The farm-level impact of herbicide-tolerant soybeans in Romania. AgBioForum, 8, 5, 235-241.

Bruening, G., and Lyons, J.M. (2000). The case of the FLAVR SAVR® tomato. California Agriculture, 54, pp. 6-7.

Brunet, Y., Dupont, S., Delage, S., Garrigou, D., Guyon, D., Dayau, S., Tulet, P., Pinty, J.-P., Lac, C., Escobar, J., et al. (2011). Long-distance pollen flow in large fragmented landscapes. In GM and non-GM supply chains coexistence and traceability, Y. Bertheau, ed. (Wiley Publishing), In Press.

Cardwell, M. (2003). Multifunctionality of agriculture: a European community perspective. In Agriculture and international trade: law, policy and the WTO, Cardwell, M. N. Grossman and M. R., Rodgers, C. P. (eds), CPL Press. pp. 131-164.

Cardwell, M. (2010). Public participation in the regulation of genetically modified organisms: a matter of substance or form? Environmental Law Review, 12, pp. 12-25.

Cardwell, M., and Bodiguel, L. (2005). Agriculture definition trend for advanced agriculture - comparative European Union/Great Britain/France approach. Revue du Marche Commun et de l'Union Européenne, 490, pp. 456-466.

Carlier, L., Rotar, I., and Vidican, R. (2010). The EU policy regulates and controls the farming practices. Bulletin UASVM Agriculture, 67, 1-11.

Cavaillès, E. (2009). La relance des légumineuses dans le cadre d'un plan protéine : quels bénéfices environnementaux ? In Etudes et documents, Commissariat général au développement durable - Service de l'économie, de l'évaluation et de l'intégration du développement durable, ed. (Paris, France, Commissariat général au développement durable - Service de l'économie, de l'évaluation et de l'intégration $\mathrm{du}$ développement durable), 44 p. Available at: http://www.developpementdurable.gouv.fr/IMG/pdf/E_D15.pdf

Cellini, F., Chesson, A., Colquhoun, I., Constable, A., Davies, H.V., Engel, K.H., Gatehouse, A.M.R., Karenlampi, S., Kok, E.J., Leguay, J.J., et al. (2004). Unintended effects and their detection in genetically modified crops. Food and Chemical Toxicology, 42, 10891125. 
Cerdeira, A.L., and Duke, S.O. (2006). The current status and environmental impacts of glyphosate-resistant crops: A review. Journal of Environmental Quality, 35, pp. 16331658.

Cerdeira, A.L., and Duke, S.O. (2007). Environmental impacts of transgenic herbicideresistant crops. CAB Reviews: Perspectives in Agriculture, Veterinary Science, Nutrition and Natural Resources, 2, 033, $14 \mathrm{p}$.

Chaufaux, J., Micoud, A., Delos, M., Naibo, B., Bombarde, F., Eychennes, N., Pagliari, C., Marque, G., and Bourguet, D. (2002). Transgenic maize and non target insects: what effects? Phytoma, pp. 13-16.

Codex Alimentarius (2003). Guideline for the conduct of food safety assessment of foods derived from recombinant-DNA plants. CAC/GL 45-2003. Annex 3: food safety assessment in situations of low-level presence of recombinant-DNA plant material in food. Available at:

http:/ / www.codexalimentarius.net/download/standards/10021/CXG_045e.pdf

Colbach, N. (2009). How to model and simulate the effects of cropping systems on population dynamics and gene flow at the landscape level: example of oilseed rape volunteers and their role for co-existence of GM and non-GM crops. Environmental Science and Pollution Research, 16, pp. 348-360.

Colbach, N., Monod, H., and Lavigne, C. (2009). A simulation study of the medium-term effects of field patterns on cross-pollination rates in oilseed rape (Brassica napus L.). Ecological Modelling, 220, pp. 662-672.

Coléno, F.C. (2008). Simulation and evaluation of GM and non-GM segregation management strategies among European grain merchants. Journal of Food Engineering 88, 306-314.

Commission, E. (2006). Regulation (EC) No 1907/2006 of the European parliament and of the Council of 18 December 2006 concerning the Registration, Evaluation, Authorisation and Restriction of Chemicals (REACH), establishing a European Chemicals Agency, amending Directive 1999/45/EC and repealing Council Regulation (EEC) No 793/93 and Commission Regulation (EC) No 1488/94 as well as Council Directive 76/769/EEC and Commission Directives 91/155/EEC, 93/67/EEC, 93/105/EC and 2000/21/EC. Official Jounal of the European Union, L 396, pp. 1-849.

Confédération paysanne (2002). Un plan protéine pour l'Europe (Bagnolet, France), 26 p. Available at :

http://www.confederationpaysanne.fr/images/imagesFCK/file/02/plan_proteines .pdf

Consumerchoice Consortium (2008). Do European consumers buy GM foods? European Commission: Framework 6, Project no. 518435. "Consumerchoice". Final report., 346 p. Available at:

http://www.kcl.ac.uk/schools/biohealth/research/nutritional/consumerchoice/ downloads.html

Covelli, N., and Hohots, V. (2003). The health regulation of biotech foods under the WTO agreements. Journal of International Economic Law, 6, pp. 773-795.

Csaki, C., and Lerman, Z. (1997). Land reform and farm restructuring in East Central Europe and CIS in the 1990s: Expectations and achievements after the first five years. European Review of Agricultural Economics, 24, pp. 428-452. 
Czarnak-Kłos, M., and Rodríguez-Cerezo, E. (2010). European Coexistence Bureau (ECoB). Best Practice Documents for coexistence of genetically modified crops with conventional and organic farming. 1. Maize crop production. EUR 24509 EN. In JRC Scientific and Technical Reports, DG-JRC-IPTS, ed. (Seville, SP, DG-JRC-IPTS), 72 p. Available at: http:/ / ecob.jrc.ec.europa.eu/documents/Maize.pdf

D'Agnolo, G. (2005). GMO: Human health risk assessment. Veterinary Research Communications, 29, pp. 7-11.

Dahl, E., and House, L. (2008). United States - European Union agricultural trade flows. In 110th EAAE Seminar 'System Dynamics and Innovation in Food Networks' (Innsbruck-Igls, Austria), 9 p. Available at: http://ageconsearch.umn.edu/bitstream/49841/2/Dahl-House.pdf

Darmency, H., Klein, E.K., De Garanbe, T.G., Gouyon, P.H., Richard-Molard, M., and Muchembled, C. (2009). Pollen dispersal in sugar beet production fields. Theoretical and Applied Genetics, 118, pp. 1083-1092.

Darmency, H., Vigouroux, Y., De Garambe, T.G., Richard-Molard, M., and Muchembled, C. (2007). Transgene escape in sugar beet production fields: data from six years farm scale monitoring. Environmental Biosafety Research, 6, pp. 197-206.

Davison, J. (2010). GM plants: science, politics and EC regulations. Plant Science, 178, pp. 9498.

Davison, J., and Bertheau, Y. (2007). EU regulations on the traceability and detection of GMOs: difficulties in interpretation, implementation and compliance. CAB Reviews: Perspectives in Agriculture, Veterinary Science, Nutrition and Natural Resources, 2, 14 p.

Davison, J., and Bertheau, Y. (2008). The theory and practice of European traceability regulations for GM food and feed. Cereal Foods World, 53, pp. 186-196.

de Cheveigné, S. (2004). Quand l'Europe mesure les représentations de la science : une analyse critique des Eurobaromètres. In Sciences, Médias et Société, J.L. Marec, and I. Babou, eds. (Lyon, F, Ecole normale supérieure. Lettres et Sciences Humaines. Laboratoire JE 2419. Communication, culture et société.), pp. 45-55.

de Jong, T.J. (2010). General surveillance of genetically modified plants in the EC and the need for controls. Journal Fur Verbraucherschutz Und Lebensmittelsicherheit-Journal of Consumer Protection and Food Safety, 5, pp. 181-183.

DEFRA (2006). Consultation on proposals for managing the coexistence of GM, conventional and organic crops (DEFRA, UK), 92 p. Available at:

http://www.defra.gov.uk/environment/quality/gm/crops/documents/gmcoexi st-condoc.pdf

Demont, M., Daems, W., Dillen, K., Mathijs, E., Sausse, C., and Tollens, E. (2008). Regulating coexistence in Europe: beware of the domino-effect! Ecological Economics, 64, pp. 683-689.

Demont, M., Devos, Y., and Sanvido, O. (2010). Towards flexible coexistence regulations for GM crops in the EU. Eurochoices, 9, pp. 18-24.

Demont, M., Dillen, K., Daems, W., Sausse, C., Tollens, E., and Mathijs, E. (2009). On the proportionality of EU spatial ex ante coexistence regulations. Food Policy, 34, pp. 508-518.

Desclaux, D., Nolot, J., Chiffoleau, Y., Gozé, E., and Leclerc, C. (2008). Changes in the concept of genotype $\times$ environment interactions to fit agriculture diversification 
and decentralized participatory plant breeding: pluridisciplinary point of view. Euphytica, 163, pp. 533-546.

Desquilbet, M., and Bullock, D.S. (2010). On the proportionality of EU spatial ex ante coexistence regulations: a comment. Food Policy, 35, pp. 87-90.

Devos, Y., Demont, M., Dillen, K., Reheul, D., Kaiser, M., and Sanvido, O. (2009). Coexistence of genetically modified (GM) and non-GM crops in the European Union. A review. Agronomy for Sustainable Development, 29, pp. 11-30.

Devos, Y.A. (2008). Transgenic crops: a kaleidoscope impact analysis. PhD Thesis. Department of plant production, faculty of bioscience engineering (Ghent, BE, Ghent University), 342 p. Available at:

http:/ / www.criticalphilosophy.ugent.be/index.php?id=2\&type=file

DG AGRI European Commission (2007). Economic impact of unapproved GMOs on EU feed imports and livestock production (Brussels, B, European Commission). 11 p. Available at:

http://ec.europa.eu/agriculture/envir/gmo/economic_impactGMOs_en.pdf

Dinu, T., Alecu, I.N., and Stoian, E. (2010). Assessing the economic impact and the traceability costs in the case of banning the cultivation of GM soybean in Romania. In 10th International Symposium " Prospects of Agriculture and Rural Areas Development in the context of Global Climate Change ", Session "Management, Marketing, Accounting, Financial Analysis, Finance", M. Draghici, and M. Berca, eds. (20-21 May 2010, Bucharest, Romania, RAWEX COMS Publishing House in co-editing with DO-MINOR Publishing House), pp. 62-67.

Dobbs, M. (2011). Legalising general prohibitions on cultivation of genetically modified organisms. German Law Journal, 11, pp. 1347-1372.

Dobrescu, M., Henard, M.-C., Krautgartner, R., Lieberz, S., and the group of FAS oilseeds specialists in the EU (2009). EU-27. Soybean imports from the United States still impeded. In EU-27, USDA GAIN, ed. (Vienna, Austria), 12 p. Available at: http:/ / gain.fas.usda.gov/Recent\%20GAIN\%20Publications/EU-

$27 \%$ 20Soybean $\% 20$ Imports $\% 20$ from $\% 20$ the $\%$ 20United $\% 20$ States $\% 20$ Still $\% 20$ Imped ed_Vienna_EU-27_11-3-2009.pdf

Ebert, I., and Lahnstein, C. (2008). GMO liability: options for insurers. In Economic Loss Caused by Genetically Modified Organisms, B.A. Koch, ed. (Springer Vienna), pp. 577581.

EFSA (2008). Environmental risk assessment of genetically modified plants - Challenges and approaches. Paper presented at: EFSA Scientific Colloquium Summary Report (Parma, Italy, EFSA). Available at: http://www.efsa.europa.eu/fr/colloquiagmoera/publication/colloquiagmoera.pdf

EFSA GMO Panel (2004). Guidance document of the scientific panel on genetically modified organisms for the risk assessment of genetically modified plants and derived food and feed. The EFSA Journal, 99, 1-94.

EFSA GMO Panel (2006a). Guidance document of the scientific panel on genetically modified organisms for the risk assessment of genetically modified microorganisms and their derived products intended for food and feed use. The EFSA Journal, 374, pp. 1-115. Available at: http://www.efsa.europa.eu/fr/scdocs/scdoc/374.htm 
EFSA GMO panel (2006b). Opinion of the scientific panel on genetically modified organisms on the post market environmental monitoring (PMEM) of genetically modified plants (Question No EFSA-Q-2004-061). The EFSA Journal, 319, 1-27.

EFSA GMO Panel (2010). Scientific opinion. Guidance on the environmental risk assessment of genetically modified plants. The EFSA Journal, 8, 1-111.

EFSA GMO Panel. (2011) Guidance on the Post-Market Environmental Monitoring (PMEM) of genetically modified plants. EFSA Journal 9:2316.

Elbehri, A. (2007). The changing face of the U.S. grain system differentiation and identity preservation trends. Economic Research Report - Economic Research Service, USDA, 39 p. Available at: http://www.ers.usda.gov/publications/err35/err35.pdf

EU working group (2003). Appendix 1: EU working group on insect resistance management: harmonised insect resistance management (IRM) plan for cultivation of Bt maize in the EU, 28 p. Available at:

http://ec.europa.eu/food/food/biotechnology/docs/IRM_plan.pdf

European Commission (1985). Council Directive 85/374/EEC of 25 July 1985 on the approximation of the laws, regulations and administrative provisions of the Member States concerning liability for defective products Official Jounal of the European Communities, L 210, pp. 29-33.

European Commission. (2011) Commission Regulation (EU) No 619/2011 of 24 June 2011 laying down the methods of sampling and analysis for the official control of feed as regards presence of genetically modified material for which an authorisation procedure is pending or the authorisation of which has expired (Text with EEA relevance). Official Jounal of the European Union L 166:9-15.

European Commission (1997). Regulation (EC) No 258/97 of the European Parliament and of the Council of 27 January 1997 concerning novel foods and novel food ingredients. Official Journal of the European Communities, L 043, pp. 1-6.

European Commission (2000a). Commission regulation (EC) No 49/2000 of 10 January 2000 amending Council Regulation (EC) No 1139/98 concerning the compulsory indication on the labelling of certain foodstuffs produced from genetically modified organisms of particulars other than those provided for in Directive 79/112/EEC. Official Journal of the European Communities, L 6, pp. 13-14.

European Commission (2000b). Regulation (EC) No 50/2000 of 10 January 2000 on the labelling of foodstuffs and food ingredients containing additives and flavourings that have been genetically modified or have been produced from genetically modified organisms. Official Journal of the European Communities, L 6, 15-17.

European Commission (2001). Directive 2001/18/EC of the European Parliament and the Council of 12 March 2001 on the deliberate release into the environment of genetically modified organisms and repealing Council Directive 90/220/EEC. Official Journal of the European Communities, L 106, 1-38.

European Commission (2002a). Council decision 2002/811/EC of 3 October 2002 establishing guidance notes supplementing Annex VII to Directive 2001/18/EC of the European Parliament and of the Council on the deliberate release into the environment of genetically modified organisms and repealing Council Directive 90/220/EEC. Official Journal of the European Communities, L 280, pp. 27-36.

European Commission (2002b). Council decision 2002/812/EC of 3 October 2002 establishing pursuant to Directive 2001/18/EC of the European Parliament and of 
the Council the summary information format relating to the placing on the market of genetically modified organisms as or in products. Official Journal of the European Communities, L 280, pp. 37-61.

European Commission (2002c). Council decision 2002/813/EC of 3 October 2002 establishing, pursuant to Directive 2001/18/EC of the European Parliament and of the Council, the summary notification information format for notifications concerning the deliberate release into the environment of genetically modified organisms for purposes other than for placing on the market. Official Journal of the European Communities, L 280, pp. 62-83.

European Commission (2002d). Regulation (EC) No 178/2002 of the European Parliament and of the Council of 28 January2002 laying down the general principles and requirements of food law, establishing the European Food Safety Authority and laying down procedures in matters of food safety. Official Journal of the European Communities, L 31, pp. 1-24.

European Commission (2003a). Commission Recommendation of 23 July 2003 on guidelines for the development of national strategies and best practices to ensure the coexistence of genetically modified crops with conventional and organic farming (notified under document number C(2003) 2624). (2003/556/CE). Official Journal of the European Communities, L 189, pp. 36-47.

European Commission (2003b). Directive 2003/4/EC of the European Parliament and of the Council of 28 January 2003 on public access to environmental information and repealing Council Directive 90/313/EEC. Official Jounal of the European Union, L 41, pp. 26-32.

European Commission (2003c). Regulation (EC) No 1829/2003 of the European Parliament and of the Council of 22 September 2003 on genetically modified food and feed. Official Journal of the European Union, L 268, pp. 1-23.

European Commission (2003d). Regulation (EC) No 1830/2003 of the European Parliament and of the Council of 22 September 2003 concerning the traceability and labelling of genetically modified organisms and the traceability of food and feed products produced from genetically modified organisms and amending Directive 2001/18/EC. Official Journal of the European Union, L 268, pp. 24-28.

European Commission (2004a). Commission decision No 2004/204/EC of 23 February 2004 laying down detailed arrangements for the operation of the registers for recording information on genetic modifications in GMOs, provided for in Directive 2001/18/EC of the European Parliament and of the Council. Official Journal of the European Union, L 065, pp. 20-22.

European Commission (2004b). Commission recommendation No 2004/787 of 4 october 2004 on technical guidance for sampling and detection of genetically modified organisms as or in products in the context of Regulation (EC) No 1830/2003. Official Journal of the European Union, L 348, pp. 18-26.

European Commission (2004c). Directive 2004/35/CE of the European Parliament and of the Council of 21 April 2004 on environmental liability with regard to the prevention and remedying of environmental damage. Official Journal of the European Union, L 143, pp. 56-75.

European Commission (2004d). Regulation (EC) No 882/2004 of the European Parliament and of the Council of 29 April 2004 on official controls performed to ensure the 
verification of compliance with feed and food law, animal health and animal welfare rules. Official Jounal of the European Union, L 165, pp. 1-141.

European Commission (2006a). Commission Regulation (EC) No 1981/2006 of 22 December 2006 on detailed rules for the implementation of Article 32 of Regulation (EC) No 1829/2003 of the European Parliament and of the Council as regards the Community reference laboratory for genetically modified organisms (Text with EEA relevance), Official Journal of the European Union, L 368, pp. 99-103.

European Commission (2006b). Communication from the Commission to the Council and the European Parliament. Report on the implementation of national measures on the coexistence of genetically modified crops with conventional and organic farming. \{SEC(2006) 313\}. COM/2006/0104 final, 10 p. Availabel at: http:/ /ec.europa.eu/agriculture/coexistence/com104_en.pdf

European Commission (2006c). Regulation (EC) No 1367/2006 of the European Parliament and of the Council of 6 September 2006 on the application of the provisions of the Aarhus Convention on Access to Information, Public Participation in Decisionmaking and Access to Justice in Environmental Matters to Community institutions and bodies. Official Jounal of the European Union, L 264, pp. 13-19.

European Commission (2006d). Report from the Commission to the Council and the European Parliament on the implementation of Regulation (EC) No 1830/2003 concerning the traceability and labelling of genetically modified organisms and the traceability of food and feed products produced from genetically modified organisms and amending Directive 2001/18/EC. 13 p. Available at: http://eurlex.europa.eu/LexUriServ/LexUriServ.do?uri=COM:2006:0197:FIN:EN:PDF

European Commission (2007a). Council Regulation (EC) No 834/2007 of 28 June 2007 on organic production and labelling of organic products and repealing Regulation (EEC) No 2092/91. Official Jounal of the European Union, L 189, pp. 1-23.

European Commission (2007b). Directive 2007/2/EC of the European Parliament and of the Council of 14 March 2007 establishing an Infrastructure for Spatial Information in the European Community (INSPIRE). Official Jounal of the European Union, L 108, pp. 1-14.

European Commission (2008a). Commission Regulation (EC) No 889/2008 of 5 September 2008 laying down detailed rules for the implementation of Council Regulation (EC) No 834/2007 on organic production and labelling of organic products with regard to organic production, labelling and control. Official Jounal of the European Union, L 250, pp. 1-84.

European Commission (2008b). Report from the Commission to the Council and the European Parliament on the implementation of Regulation (EC) No 1830/2003 concerning the traceability and labelling of genetically modified organisms and the traceability of food and feed products produced from genetically modified organisms and amending Directive 2001/18/EC. COM (2008) 560 final. 11 p. Available at:

http://eur-

lex.europa.eu/LexUriServ/LexUriServ.do?uri=COM:2008:0560:FIN:EN:PDF

European Commission (2009a). Commission decision No 2009/770/EC of 13 October 2009 establishing standard reporting formats for presenting the monitoring results of the deliberate release into the environment of genetically modified organisms, as or in 
products, for the purpose of placing on the market, pursuant to Directive 2001/18/EC of the European Parliament and of the Council. Official Journal of the European Union, L 275, pp. 9-27.

European Commission (2009b). Commission Decision of 13 October 2009 establishing standard reporting formats for presenting the monitoring results of the deliberate release into the environment of genetically modified organisms, as or in products, for the purpose of placing on the market, pursuant to Directive 2001/18/EC of the European Parliament and of the Council. (notified under document C(2009) 7680). Official Journal of the European Union, L 975, pp. 9-27.

European Commission (2009c). Council regulation (EC) No 73/2009 of 19 January 2009 establishing common rules for direct support schemes for farmers under the common agricultural policy and establishing certain support schemes for farmers, amending Regulations (EC) No 1290/2005, (EC) No 247/2006, (EC) No 378/2007 and repealing Regulation (EC) No 1782/2003. Official Jounal of the European Union, L 30, pp. 16-99.

European Commission (2009d). Regulation (EC) No 1107/2009 of the Euopean Parliamne and of the Council of 21 October 2009 concerning the placing of plant protection products on the market and repealing Council Directives 79/117/EEC and 91/414/EEC. Official Jounal of the European Union, L 309, pp. 1-50.

European Commission (2009e). Report from the Commission to the Council and the European Parliament on the coexistence of genetically modified crops with conventional and organic farming (SEK(2009) 408). European Commission, ed. 12 p. Available at:

http://eur-

lex.europa.eu/LexUriServ/LexUriServ.do?uri=COM:2009:0153:FIN:EN:PDF

European Commission (2010a). Commission Recommendation of 13 July 2010 on guidelines for the development of national co-existence measures to avoid the unintended presence of GMOs in conventional and organic crops (2010/C 200/01). Official Journal of the European Union, C 200, pp. 1-5.

European Commission (2010b). A decade of EU-funded GMO research (2001 - 2010). EUR 24473, European Commission, ed. (Brussels, Belgium, European Commission), 264 p. Available at: http://ec.europa.eu/research/biosociety/pdf/a_decade_of_eufunded_gmo_research.pdf

European Commission (2011). Report from the Commission to the European parliament and the Council on socio-economic implications of GMO cultivation on the basis of Member States contributions, as requested by the Conclusions of the Environment Council of December 2008. , D.-S. European Commission, ed. (Brussels, Belgium), 11 p. Available at:

http:/ /ec.europa.eu/food/food/biotechnology/reports_studies/docs/socio_econ omic_report_GMO_fr.pdf

European Economic and Social Committee (2011). Opinion of the European Economic and Social Committee on the 'Proposal for a Regulation of the European Parliament and of the Council amending Directive 2001/18/EC as regards the possibility for the Member States to restrict or prohibit the cultivation of GMOs in their territory' $\operatorname{COM}(2010) 375$ final - 2010/0208 (COD). (2011/C 54/16). Official Jounal of the European Union, C 54, pp. 51-57. 
European Parliament. Directorate-General for Internal Policies (2010). The evaluations of the impact of reforms that have affected the sector and the needs of European livestock system. In Policy Department Structural and cohesion policies B, E.P.D.f.I. Policies, ed. (Brussels, Belgium), $31 \mathrm{p}$.

http://www.europarl.europa.eu/activities/committees/studies/download.do?lan guage $=$ en \&file $=32695$

Eurostat. European Commission (2010). Agricultural statistics. Main results - 2008-09. In Eurostat pocketbooks, E. Commission, ed. (Eurostat), 186 p. Available at: http://epp.eurostat.ec.europa.eu/cache/ITY_OFFPUB/KS-ED-10-001/EN/KSED-10-001-EN.PDF

Filip, L., Miere, D., and Indrei, L.L. (2004). Genetically modified foods. Advantages and human health risks. Revista medico-chirurgicala a Societatii de Medici si Naturalisti din Iasi, 108, pp. 838-842.

Finck, M., Seitz, H., and Beismann, H. (2006). Concepts for general surveillance: VDI proposals standardisation and harmonisation in the field of GMO-monitoring. Journal fur Verbraucherschutz und Lebensmittelsicherheit, 1, pp. 11-14.

Fok, M. (2010). Un état de coexistence du soja transgénique et conventionnel au Paraná (Brésil). Economie rurale, 320, 53-68.

Foster, M. (2007). Challenges for agricultural markets, coexistence, segmentation of grain markets, costs and opportunities. ABARE CONFERENCE PAPER 07.9. Paper presented at: GMCC07 Third International Conference on Coexistence between Genetically Modified (GM) and non-GM based Agricultural Supply Chains. Seville, Spain, DG-JRC-IPTS (ed.). Available at:

http://www.abare.gov.au/publications_html/conference/conference_07/agric_m arkets.pdf

Foster, M. (2010). Evidence of price premiums for non-GM grains in world markets. In Australian Agricultural and Resource Economics Society (Adelaide, Australia, ABARE, Australia), 16 p. Available at:

http://www.abare.gov.au/publications_html/conference/conference_10/AARES -4.pdf

GAO (2008). Agencies are proposing changes to improve oversight, but could take additional steps to enhance coordination and monitoring. In Report to the Committee on Agriculture, Nutrition, and Forestry, US Senate (U.S. Government Accountability Office), 109 p. Available at: http://www.gao.gov/products/GAO09-60

Garcia-Alonso, M., Jacobs, E., Raybould, A., Nickson, T.E., Sowig, P., Willekens, H., Van der Kouwe, P., Layton, R., Amijee, F., Fuentes, A.M., et al. (2006). A tiered system for assessing the risk of genetically modified plants to non- target organisms. Environmental Biosafety Research, 5, pp. 57-65.

Gaskell, G., Allansdottir, A., Allum, N., Corchero, C., Fischler, C., Hampel, J., Jackson, J., Kronberger, N., Mejlgaard, N., Revuelta, G., et al. (2006). Europeans and Biotechnology in 2005: Patterns and Trends. Eurobarometer 64.3. A report to the European Commission's Directorate-General for Research. In Eurobarometer, European Commission, ed. (Brussels, Belgium), 85 p. Available at: http://www.cibpt.org/docs/2006-jul-eurobarometro-bio-2nd-ed.pdf 
Gaskell, G., Stares, S., Allansdottir, A., Allum, N., Castro, P., Esmer, Y., Fischler, C., Jackson, J., Kronberger, N., Hampel, J., et al. (2010). Europeans and biotechnology in 2010. Winds of change? A report to the European Commission's Directorate-General for Research. EUR 24537 EN. In Research*eu Studies and reports (Brussels, Belgium, European Commission), 176 p. Available at: http://ec.europa.eu/public_opinion/archives/ebs/ebs_341_winds_en.pdf

Gathmann, A. (2009). National implementation plan for MON810 monitoring in Germany A way forward to improve General Surveillance? Journal fur Verbraucherschutz und Lebensmittelsicherheit 3, 50-50.

Gathmann, A., and Bartsch, D. (2006). National coordination of GMO monitoring - a concept for Germany. Journal fur Verbraucherschutz und Lebensmittelsicherheit, 1, pp. 45-48.

Gelder, J.W.v., Kammeraat, K., and Kroes, H. (2008). Soy consumption for feed and fuel in the European Union. A research paper prepared for Milieudefensie (Friends of the Earth Netherlands), $22 \mathrm{p}$. http://www.foeeurope.org/agrofuels/FFE/Profundo\%20report\%20final.pdf

Graef, F., Zughart, W., Hommel, B., Heinrich, U., Stachow, U., and Werner, A. (2005). Methodological scheme for designing the monitoring of genetically modified crops at the regional scale. Environmental Monitoring and Assessment, 111, 1-26.

Green, R., and Hervé, S. (2006). IP - Traceability and grains traders: ADM, Bunge, Cargill, Dreyfus. INRA Les cahiers d'ALISS, 03, 86 p. Available at:

http://www.prodinra.inra.fr/prodinra/pinra/data/2007/11/PROD200752c85e26 _20071115125832834.pdf

Grossman, M.R. (2003). Multifunctionality and non-trade concerns. In Agriculture and international trade: law, policy and the WTO, Michael N Cardwell, Margaret R Grossman and Christopher Rodgers (eds), CABI. pp. 85-129.

Gruber, S., Colbach, N., Barbottin, A., and Pekrun, C. (2008). Post-harvest gene escape and approaches for minimizing it. CAB Reviews: Perspectives in Agriculture, Veterinary Science, Nutrition and Natural Resources, 3, 17 p.

Gryson, N., and Eeckhout, M. (2011). Co-existence and traceability in supply chains: a case study on Belgian compound feed. In GM and non-GM supply chains: their coexistence and traceability, Y. Bertheau, ed. (London, UK, Wiley Ltd.). In Press.

Haggett, S. (2008). Towards a multipurpose neural network approach to novelty detection (University of Kent), 236 p. Available at: http:/ / kar.kent.ac.uk/24133/1/Towards_Detection.pdf

Hannachi, M., Coléno, F.C., and Assens, C. (2009). Collective strategies and coordination for the management of coexistence: the case studies of Alsace and western South of France. Paper presented at: Fourth International Conference on Coexistence between Genetically Modified (GM) and non-GM based Agricultural Supply Chains (Melbourne, AU). Available at: http://assens.perso.neuf.fr/GMO2009.pdf

Hansen, J., Lin, W., Tuan, F., Marchant, M.A., Kalaitzandonakes, N., Zhong, F., and Song, B. (2007). Commercialization of herbicide-tolerant soybeans in China: perverse domestic and international trade effects. In American Agricultural Economics Association Annual Meeting (Portland, OR, USA), 33 p. Available at: http://ageconsearch.umn.edu/bitstream/9906/1/sp07ha03.pdf

Hardin, G. (1968). Tragedy of commons. Science, 162, 1243-1248.

Hardin, G. (1998). Extensions of "The Tragedy of the Commons". Science, 280, 682-683. 
Harrell, F.E. (2001). Regression modeling strategies. With applications to linear models, logistic regression, and survival analysis. Springer verlag.

Hasha, G. (2002). Livestock feeding and feed imports in the European Union-A decade of change. FDS-0602-01. In Electronic Outlook Report from the Economic Research Service, ERS, USDA, ed., 28 p. Available at: http://m.usda.mannlib.cornell.edu/usda/ers/FDS/2000s/2002/FDS-07-032002_Special_Report.pdf

Häusling M., Rapporteur of the Committee on Agriculture and Rural Development of the European Parliament (2011). The EU protein deficit: what solution for a long-standing problem? (2010/2111(INI)). In Report, European Parliament, ed. Available at: http:/ / www.europarl.europa.eu/sides/getDoc.do?pubRef=-/ /EP//NONSGML+ REPORT+A7-2011-0026+0+DOC+PDF+V0//EN\&language $=\mathrm{EN}$

Headey, D. (2011). Rethinking the global food crisis: the role of trade shocks. Food Policy, 36, pp. 136-146.

Heisey, P.W., King, J.L., and Rubenstein, K.D. (2005). Patterns of public-sector and privatesector patenting in agricultural biotechnology. AgBioForum, 8, 73.

Heisey, P.W., Srinivasan, C.S., and Thirtle, C. (2001). Public sector plant breeding in a privatizing world. In Agriculture Information Bulletin, E.R.S. Resource economics Division, USDA, ed. (Washington, DC, USA, Resource economics Division, Economic research Service, USDA). Available at: http://www.ers.usda.gov/publications/aib772/aib772.pdf

Henle, K., Alard, D., Clitherow, J., Cobb, P., Firbank, L., Kull, T., McCracken, D., Moritz, R.F.A., Niemelä, J., Rebane, M., et al. (2008). Identifying and managing the conflicts between agriculture and biodiversity conservation in Europe - A review. Agriculture Ecosystems \& Environment, 124, pp. 60-71.

Hepburn, P., Howlett, J., Boeing, H., Cockburn, A., Constable, A., Davi, A., de Jong, N., Moseley, B., Oberdorfer, R., Robertson, C., et al. (2008). The application of postmarket monitoring to novel foods. Food and Chemical Toxicology, 46, pp. 9-33.

Hintermann, U., Weber, D., Zangger, A., and Schmill, J. (2002). Biodiversity monitoring in Switzerland BDM - interim report. Environmental series. No. 342, Forest and Landscape, Swiss Agency for the Environment, Berne, Switzerland, ed. Available at: www.umwelt-schweiz.ch/buwal/shop/files/pdf/phpamJ0T6.pdf

James, C. (2011). Global status of commercialized biotech / GM crops: 2010. In ISAAA Brief, ISAAA, ed. (Ithaca, NY, USA).

Jank, B., Rath, J., and Gaugitsch, H. (2006). Co-existence of agricultural production systems. Trends in Biotechnology, 24, pp. 198-200.

Kaditi, E., and Swinnen, J.F.M. (2006). Trade Agreements, Multifunctionality and EU Agriculture. The Centre for European Policy Studies, Brussels, Belgium. 323 p.

Kanter, J. (2010). E.U. signals big shift on genetically modified crops. In The New-York Times (New-York, USA). Available at:

http://www.nytimes.com/2010/05/10/business/energyenvironment/10green.html?_r=1\&src=busln

Kawata, M., Murakami, K., and Ishikawa, T. (2009). Dispersal and persistence of genetically modified oilseed rape around Japanese harbors. Environmental Science and Pollution Research, 16, pp. 120-126. 
Kim, C.-G., Yi, H., Park, S., Yeon, J.E., Kim, D.Y., Kim, D.I., Lee, K.-H., Lee, T.C., Paek, I.S., Yoon, W.K., et al. (2006). Monitoring the occurrence of genetically modified soybean and maize around cultivated fields and at a grain receiving port in Korea. Journal of Plant Biology, 49, pp. 218-223.

Konduru, S.P. (2008). Three essays on the potential economic impacts of biotech crops in the presence of asynchronous regulatrory approval. PhD Thesis. Faculty of the Graduate School, Agricultural Economics (Columbia, U.S.A., University of Missouri-Columbia), 145 p. Available at: https://mospace.umsystem.edu/xmlui/handle/10355/6642

Konefal, J. and Busch, L. (2010). Markets of multitudes: how biotechnologies are standardising and differentiating corn and soybeans. Sociologia Ruralis, 50, 4, pp. 409-427

Kontoleon, A., and Yabe, M. (2006). Market segmentation analysis of preferences for GM derived animal foods in the UK. Journal of Agricultural $\mathcal{E}$ Food Industrial Organization, 4, Article 8.

Krautgartner, R., Henard, M.-C., Lieberz, S., Boshnakova, M., and the group of FAS oilseeds specialists in the EU (2010a). EU-27. Oilseeds - Increased domestic soybean \& soybean meal production. In EU-27, USDA GAIN, ed. (Vienna, Austria), 14 p. Available at:

http:/ / gain.fas.usda.gov/Recent\%20GAIN\%20Publications/Oilseeds\%20\%20Incre ased\%20Domestic\%20Soybean\%20and\%20Soybean\%20Meal\%20Production_Vienn a_EU-27_11-30-2010.pdf

Krautgartner, R., Henard, M.-C., Lieberz, S., Dobrescu, M., Flach, B., Wideback, A., Guerrero, M., Bendz, K., and the group of FAS oilseeds specialists in the EU (2010b). EU-27. Oilseeds and products annual. 2010. In EU-27, USDA GAIN, ed. (Berlin, Germany), 33 p. Available at :

http:/ / gain.fas.usda.gov/Recent\%20GAIN\%20Publications/Oilseeds \%20and \%20P roducts\%20Annual_Berlin_EU-27_4-19-2010.pdf

Laisney, C. (2011). L'évolution de l'alimentation en France. Tendances émergentes et ruptures possibles. Futuribles, pp. 5-23.

Laudadio, V., Tufarelli, V., Dario, M., Cazzato, E., and Modugno, G.d. (2009). Evaluation of dehulled and micronized lupin (Lupinus albus L.) and pea (Pisum sativum L.) seed meal as an alternative protein source in diets for pre-laying hens. World Poultry Science Association (WPSA), 2nd Mediterranean Summit of WPSA, Antalya, Turkey, 4-7 October 2009, pp. 495-498.

Laurent, C., Berriet-Solliec, M., Kirsch, M., Labarthe, P., and Trouvé, A. (2010). Multifunctionality of agriculture, public policies and scientific evidences: some critical issues of contemporary controversies. Applied Studies in Agribusiness and Commerce - APSTRACT, pp. 53-58.

Le Bail, M., Lecroart, B., Gauffreteau, A., Angevin , F., and Messéan, A. (2010). Effect of the structural variables of landscapes on the risks of spatial dissemination between GM and non-GM maize. European Journal of Agronomy, 33, pp. 12-23.

Lecoq, E., Holt, K., Janssens, J., Legris, G., Pleysier, A., Tinland, B., and Wandelt, C. (2007). General surveillance: roles and responsibilities, the industry view. Journal Fur Verbraucherschutz Und Lebensmittelsicherheit-Journal of Consumer Protection and Food Safety, 2, pp. 25-28. 
Lee, B., Kim, C.G., Park, J.Y., Park, K.W., Kim, H.J., Yi, H., Jeong, S.C., Yoon, W.K., and Kim, H.M. (2009). Monitoring the occurrence of genetically modified soybean and maize in cultivated fields and along the transportation routes of the Incheon Port in South Korea. Food Control, 20, pp. 250-254.

Lehuger, S., Gabrielle, B., and Gagnaire, N. (2009). Environmental impact of the substitution of imported soybean meal with locally-produced rapeseed meal in dairy cow feed. Journal of Cleaner Production, 17, pp. 616-624.

LMC International (2009a). Evaluation of measures applied under the Common Agricultural Policy to the protein crop sector. Case study monographs (Report to the European Commission), LMC International, ed., 231 p. Available at: http://ec.europa.eu/agriculture/eval/reports/protein_crops/case_studies_en.pdf

LMC International (2009b). Evaluation of measures applied under the Common Agricultural Policy to the protein crop sector. Main Report (Report to the European Commission.), L. International, ed., pp. vIII, ii, 169. Available at: http:/ / ec.europa.eu/agriculture/eval/reports/protein_crops/fulltext_en.pdf

Lu, Y., Wu, K., Jiang, Y., Xia, B., Li, P., Feng, H., Wyckhuys, K.A.G., and Guo, Y. (2010). Mirid bug outbreaks in multiple crops correlated with wide-scale adoption of $\mathrm{Bt}$ cotton in China. Science, 328, pp. 1151-1154.

Marsden, T. (2008). Agri-food contestations in rural space: GM in its regulatory context. Geoforum, 39, pp. 191-203.

Messéan, A., Angevin, F., Gomez-Barbero, M., Menrad, K., and Rodriguez-Cerezo, E. (2006). New case studies on the coexistence of GM and non-GM crops in European agriculture. EUR22102 EN (Seville, Spain, DG-JRC-IPTS), 116 p. Available at: http://www.jrc.es/home/pages/eur22102enfinal.pdf

Messéan, A., Squire, G., Perry, J., Angevin, F., Gomez, M., Townend, P., Sausse, C., Breckling, B., Langrell, S., Dzeroski, S., et al. (2009). Sustainable introduction of GM crops into european agriculture: a summary report of the FP6 SIGMEA research project. OCL - Oleagineux, Corps Gras, Lipides, 16, pp. 37-51.

Milanesi, J. (2008). Analyse des coûts induits sur les filières agricoles par les mises en culture d'organismes génétiquement modifiés (OGM) - Etude sur le maïs, le soja et le poulet Label Rouge, C.d.R.e.G. (CREG). ed. (Pau, France, Université de Pau et des Pays de l'Adour), $123 \mathrm{p}$. Availabel at :

Milanesi, J. (2009). Quel avenir pour les filières animales " sans OGM » en France? Illustration par le poulet Label Rouge. In 3èmes journées de recherches en sciences sociales INRA SFER CIRAD (Montpellier, France). Available at : http://hal.archives-ouvertes.fr/hal-00521222/en/

Milanesi, J. (2011). Current and future availability of non-genetically modified soybean seeds in the U.S., Brazil and Argentina. In GM and non-GM supply chains: their coexistence and traceability, Y. Bertheau, ed. (Wiley Publishing Ltd.), In Press.

Miller, H.I. (2010). Split approvals and hot potatoes. Nature Biotechnology, 28, pp. 552-553.

Monkemeyer, W., Schmidt, K., Beissner, L., Schiemann, J., and Wilhelm, R. (2006). A critical examination of the potentials of existing German networks for GMO monitoring. Journal fur Verbraucherschutz und Lebensmittelsicherheit, 1, 67-71.

Monsanto Co. (2006). Monitoring report. Mon810 cultivation. Czech republic, France, Germany, Portugal and Spain. 2005, 236 p. Available at: https://yieldgard.eu/enus/YieldGardLibraryGrower/2005\%20YieldGard\%20Monitoring\%20Report.pdf 
Monsanto Co. (2009a). Annual monitoring report on the cultivation of MON 810 in 2008. Czech Republic, Germany, Portugal, Slovakia, Poland, Romania and Spain, 388 p. Available at: https://yieldgard.eu/enus/YieldGardLibraryGrower/2008\%20YieldGard\%20Monitoring\%20Report.pdf

Monsanto Co. (2009b). Monitoring Report. MON 810 cultivation. Spain. 2003-2004, 57 p. Available at:

https://yieldgard.eu/enus/YieldGardLibraryGrower/20032004\%20YieldGard\%20Monitoring\%20Report.p $\mathrm{df}$

Naeve, S.L., Orf, J.H., and Miller-Garvin, J. (2010). 2010 analysis of the U.S. non-GMO food soybean variety pipeline. In Japan Soy Food Summit (Tokyo, Japan). Available at: http://soybase.org/meeting_presentations/soybean_breeders_workshop/SBW_20 11/Naeve.pdf

Noussair, C., Robin, S., and Ruffieux, B. (2004). Revealing consumers' willingness-to-pay: A comparison of the BDM mechanism and the Vickrey auction. Journal of Economic Psychology, 25, pp. 725-741.

Nowicki, P., Aramyan, L., Baltussen, W., Dvortsin, L., Jongeneel, R., Domínguez, I.P., Wagenberg, C.v., Kalaitzandonakes, N., Kaufman, J., Miller, D., et al. (2010). Study on the implications of asynchronous GMO approvals for EU imports of animal feed products. Final report (Contract $\left.\mathrm{N}^{\circ} 30-\mathrm{CE}-0317175 / 00-74\right)$. Executed on behalf of Directorate-General for Agriculture and Rural Development, European Commission. Available at: http:/ / ec.europa.eu/agriculture/analysis/external/asynchronous-gmoapprovals/full-text_en.pdf

Orf, J.H. (2004). Overview of recent genetic improvement in public and private breeding programs in the USA. pp. 220-227.

Ostergard, H., Finckh, M.R., Fontaine, L., Goldringer, I., Hoad, S.P., Kristensen, K., van Bueren, E.T.L., Mascher, F., Munk, L., and Wolfe, M.S. (2009). Time for a shift in crop production: embracing complexity through diversity at all levels. Journal of the Science of Food and Agriculture, 89, pp. 1439-1445.

Otiman, I.P., Badea, E.M., and Buzdugan, L. (2008). Roundup Ready soybean, a Romanian story. Bulletin of University of Agricultural Sciences and Veterinary Medicine ClujNapoca Animal Science and Biotechnologies, 65, pp. 352-357.

Owen, M., Dixon, P., Shaw, D., Weller, S., Young, B., Wilson, R., and Jordan, D. (2010). Sustainability of glyphosate-based weed management: the benchmark study. ISB News Report August 2010, 3.

Owen, M.D.K. (2009). Herbicide-tolerant genetically modified crops: resistance management. In Environmental impact of genetically modified crops, Ferry, N. and Gatehouse, A. M. R. (eds). CABI. pp. 115-164.

Pascher, K., Moser, D., Dullinger, S., Sachslehner, L., Gros, P., Traxler, A., Sauberer, N., Frank, T., and Grabherr, G. (2009). Establishment of an Austrian monitoring design to identify potential ecological effects of genetically modified plants. In Fourth International Conference on Coexistence between Genetically Modified (GM) and Non-GM based Agricultural Supply Chains (GMCC09) (Melbourne, Australia, 
GMCC09), 11 p. Available at: http://www.gmcc-09.com/wpcontent/uploads/poster_03_82-pascher_poster.pdf

Petit, S. (2009). The dimensions of land use change in rural landscapes: Lessons learnt from the GB Countryside Surveys. Journal of Environmental Management, 90, pp. 28512856.

Popp, J. (2008). The future of GM crops. Hungarian Agricultural Research, 2/3, pp. 17-20.

Pouliquen, A. (2001). Competitiveness and farm incomes in the CEES agri-food sectors. Implication before and after accession for EU markets and policies., 95 p. Available at: http:/ /ec.europa.eu/agriculture/publi/reports/ceeccomp/fullrep_en.pdf

République Française (2008). Loi $\mathrm{n}^{\circ} 2008-595$ du 25 juin 2008 relative aux organismes génétiquement modifiés. NOR: DEVX0771876L. Journal Officiel de la République française, pp. 10218-10228.

Reuter (2010). E.U. considers easing rules on biotech crops in animal feed. In The New-York Times, October 8, 2010. Available at: http://www.nytimes.com/2010/10/09/business/global/09gmo.html?_r=3\&ref=g enetic_engineering

Roberson, R. (2010). Super weeds put USDA on hotseat, CheckBiotech, 2 p.

Roebroeck, L. (2002). Factsheet soybean, T.N. Biotechnology and Consumer Foundation, ed. (The Hague, The Netherlands), $44 \mathrm{p}$. Available at: http://www.voedingscentrum.nl/resources2008/Factsheet_sojapdf.pdf

Sabalza M., Miralpeix B., Twyman R.M., Capell T. and Christou P. (2011). EU legitimizes GM crops exclusion zones. Nature Biotechnology, 29, 4, pp. 315-317.

Sanvido, O., Aviron, S., Romeis, J., and Bigler, F. (2007a). Challenges and perspectives in decision-making during post-market environmental monitoring of genetically modified crops. Journal Fur Verbraucherschutz Und Lebensmittelsicherheit-Journal of Consumer Protection and Food Safety, 2, pp. 37-40.

Sanvido, O., Romeis, J., and Bigler, F. (2007b). Ecological impacts of genetically modified crops: Ten years of field research and commercial cultivation. Advances in Biochemical Engineering/Biotechnology, 107, pp. 235-278.

Sanvido, O., Romeis, J., and Bigler, F. (2009a). An approach for post-market monitoring of potential environmental effects of Bt-maize expressing Cry1 $\mathrm{Ab}$ on natural enemies. Journal of Applied Entomology, 133, pp. 236-248.

Sanvido, O., Romeis, J., and Bigler, F. (2009b). Monitoring or Surveillance? Balancing between theoretical frameworks and practical experiences. Journal fur Verbraucherschutz und Lebensmittelsicherheit, 3, pp. 4-7.

Sanvido, O., Widmer, F., Winzeler, M., and Bigler, F. (2005). A conceptual framework for the design of environmental post-market monitoring of genetically modified plants. Environmental Biosafety Research, 4, 13-27.

Schiemann, J. (2007). Proceedings of the international workshop "Post Market Environmental Monitoring of Genetically Modified Plants: Harmonisation and Standardisation - a Practical Approach". 26-27 April, 2007, Berlin, Germany. Journal fur Verbraucherschutz und Lebensmittelsicherheit, 2, 91 p.

Schmidt, K., Mönkemeyer, W., Böttinger, P., Wilhelm, R., and Schiemann, J. (2009). Use of existing networks for post-market monitoring? Journal fur Verbraucherschutz und Lebensmittelsicherheit, 3, 13-13. 
Seitz, H., Zughart, W., Finck, M., Beismann, H., Berhorn, F., and Eikmann, T. (2010). Standardization of methods for monitoring the environmental effects of genetically modified plants, development of VDI guidelines: a final report an R \& D project (FKZ 80467 010) on behalf of the Federal Office for Nature Conservation. BfN Skripten (Bundesamt fur Naturschutz), 68 p. Available at: http://www.bfn.de/fileadmin/MDB/documents/service/Skript267.pdf

Smale, M., ed. (1998). Farmers, gene banks and crop breeding: economic analyses of diversity in wheat, maize, and rice (Springer Verlag). $288 \mathrm{p}$.

Stein, A.J., and Rodriguez-Cerezo, E. (2009). The global pipeline of new GM crops. EUR 23486 EN. In JRC scientific and technical reports, JRC-IPTS, ed. (Seville, SP, JRCIPTS), 114 p. Available at: http:/ /ftp.jrc.es/EURdoc/report_GMOpipeline_online_preprint.pdf

Stein, A.J., and Rodriguez-Cerezo, E. (2010a). International trade and the global pipeline of new GM crops. Nature Biotechnology, 28, pp. 23-25.

Stein, A.J., and Rodriguez-Cerezo, E. (2010b). Low-level presence of new GM crops: an issue on the rise for countries where they lack approval. AgBioForum, 13, pp. 173-182.

Stein, A.J., and Rodríguez-Cerezo, E. (2009). What can data on GMO field release applications in the USA tell us about the commercialisation of new GM crops? JRC52545. In JRC Technical notes, JRC-IPTS, ed., 16 p. Available at: http://ftp.jrc.es/EURdoc/JRC52545.pdf

Takada, A. (2010). China to compete with U.S., Canada in Asian market for soybean foods. In Bloomberg News. Available at: http://www.bloomberg.com/news/2010-1119/china-s-non-modified-soybeans-to-compete-with-u-s-canada-in-asianmarket.html

Tallage, Agri market forecasting (2010). Study on modelling of feed consumption in the European Union. Tender No. AGRI-2008-EVAL-09, Tallage, ed. (European Commission, DG-AGRI), 73 p. Available at: http:/ /ec.europa.eu/agriculture/analysis/external/feed/fulltext_en.pdf

Taylor, R.D., and Koo, W.W. (2010). 2010 outlook of the U.S. and world corn and soybean industries, 2009-2019, C.f.A.P.a.T. Studies, ed. (Fargo, North Dakota, USA, Department of Agribusiness and Applied Economics. North Dakota State University), 35 p. Available at:

https://ageconsearch.umn.edu/bitstream/92003/2/AgReport665\%20-

$\%$ 20Corn_and_soybean.pdf

Then, C., and Stolze, M. (2010). Economic impacts of labelling thresholds for the adventitious presence of genetically engineered organisms in conventional and organic seed. Seed purity: costs, benefits and risk management strategies for maintaining markets free from genetically engineered plants (IFOAM EU Group), 60 p. Available at: http://www.ifoam.org/about_ifoam/around_world/eu_groupnew/positions/publications/pdf/IFOAMEU_GMO-freeSeedStudy.pdf

Tinland, B. (2008). Implementation of post-market monitoring of insect-protected maize MON 810 in the UE. AFPP - 8ème Conference Internationale sur les Ravageurs en Agriculture, Montpellier SupAgro, France, 22-23 Octobre 2008, 165. Available at: http:/ / www.cabdirect.org/abstracts/20093081604.html

Tinland, B., Delzenne, P., and Pleysier, A. (2007). Implementation of a post-market monitoring for insect-protected maize MON 810 in the EU. Journal Fur 
Verbraucherschutz Und Lebensmittelsicherheit-Journal of Consumer Protection and Food Safety, 2, 7-10.

TNS Opinion \& Social (2010). Eurobaromètre 72. L'opinion publique dans l'Union Européenne (Brussels, B).

van Tongeren, F., van Meijl, H., and Surry, Y. (2001). Global models applied to agricultural and trade policies: a review and assessment. Agricultural Economics, 26, pp. 149-172.

Wal, J.M., Hepburn, P.A., Lea, L.J., and Crevel, R.W.R. (2003). Post-market surveillance of GM foods: applicability and limitations of schemes used with pharmaceuticals and some non-GM novel foods. Regulatory Toxicology and Pharmacology, 38, pp. 98-104.

Wandelt, C. (2007). Implementation of general surveillance for amflora potato cultivation Data management. Journal Für Verbraucherschutz Und Lebensmittelsicherheit-Journal of Consumer Protection and Food Safety, 2, pp. 70-71.

Wilhelm, R., Beissner, L., and Schiemann, J. (2003). Concept for the realisation of a GMOmonitoring in Germany. Nachrichtenblatt des Deutschen Pflanzenschutzdienstes, 55, pp. 258-272.

Wilhelm, R., Sanvido, O., Castanera, P., Schmidt, K., and Schiemann, J. (2009). Monitoring the commercial cultivation of $\mathrm{Bt}$ maize in Europe - conclusions and recommendations for future monitoring practice. Environmental Biosafety Research, 8, 4, pp. 219-225.

Wilhelm, R., and Schiemann, J. (2006). Does the baseline concept provide appropriate tools for decision making? Journal fur Verbraucherschutz und Lebensmittelsicherheit, 1, pp. 75-77.

Windels, P., Alcalde, E., Lecoq, E., Legris, G., Pleysier, A., Tinland, B., and Wandelt, C. (2009). General surveillance for import and processing: the EuropaBio approach. Journal fur Verbraucherschutz und Lebensmittelsicherheit, 3, pp. 14-16.

Wolt, J.D., Keese, P., Raybould, A., Fitzpatrick, J.W., Burachik, M., Gray, A., Olin, S.S., Schiemann, J., Sears, M., and Wu, F. (2010). Problem formulation in the environmental risk assessment for genetically modified plants. Transgenic Research, 19, pp. 425-436.

Zughart, W., Benzler, A., Berhorn, F., Sukopp, U., and Graef, F. (2008). Determining indicators, methods and sites for monitoring potential adverse effects of genetically modified plants to the environment: the legal and conceptional framework for implementation. Euphytica, 164, pp. 845-852. 


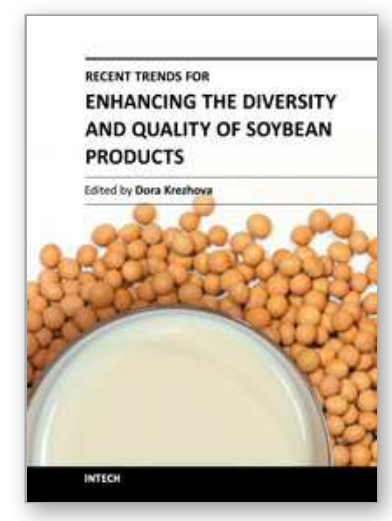

\author{
Recent Trends for Enhancing the Diversity and Quality of Soybean \\ Products \\ Edited by Prof. Dora Krezhova
}

ISBN 978-953-307-533-4

Hard cover, 536 pages

Publisher InTech

Published online 28, October, 2011

Published in print edition October, 2011

This book presents new aspects and technologies for the applicability of soybean and soybean products in industry (human food, livestock feed, oil and biodiesel production, textile, medicine) as well as for future uses of some soybean sub-products. The contributions are organized in two sections considering soybean in aspects of food, nutrition and health and modern processing technologies. Each of the sections covers a wide range of topics. The authors are from many countries all over the world and this clearly shows that the soybean research and applications are of global significance.

\title{
How to reference
}

In order to correctly reference this scholarly work, feel free to copy and paste the following:

Yves Bertheau and John Davison (2011). Soybean in the European Union, Status and Perspective, Recent Trends for Enhancing the Diversity and Quality of Soybean Products, Prof. Dora Krezhova (Ed.), ISBN: 978953-307-533-4, InTech, Available from: http://www.intechopen.com/books/recent-trends-for-enhancing-thediversity-and-quality-of-soybean-products/soybean-in-the-european-union-status-and-perspective

\section{INTECH}

open science | open minds

\section{InTech Europe}

University Campus STeP Ri

Slavka Krautzeka 83/A

51000 Rijeka, Croatia

Phone: +385 (51) 770447

Fax: +385 (51) 686166

www.intechopen.com

\section{InTech China}

Unit 405, Office Block, Hotel Equatorial Shanghai

No.65, Yan An Road (West), Shanghai, 200040, China

中国上海市延安西路65号上海国际贵都大饭店办公楼 405 单元

Phone: +86-21-62489820

Fax: +86-21-62489821 
(C) 2011 The Author(s). Licensee IntechOpen. This is an open access article distributed under the terms of the Creative Commons Attribution 3.0 License, which permits unrestricted use, distribution, and reproduction in any medium, provided the original work is properly cited. 